\title{
EI Padrenuestro como obra de arte y belleza
}

\author{
Luis Ángel Montes Peral \\ Director del Aula de Teología de la UVa. Campus de Palencia \\ Prof. Emérito Estudio Teológico Agustiniano
}

Para todos los obispos y sacerdotes, que este año de pandemia 2021, celebran sus bodas de oro de ordenación sacerdotal.

Para que sigan siendo fieles a su ministerio con la ayuda de la Trinidad Santa.

Barruelo de Santullán (Palencia) 01 de agosto de 1971, lugar y día de mi ordenación sacerdotal.

Resumen: El Padrenuestro constituye el resumen perfecto de la vida cristiana y puede considerarse como su mejor oración. Sorprende la facilidad con que ha sido aprendido y rezado por todas las generaciones creyentes, debido a los valores intrínsecos existentes en su sencillo pero hondo contenido. Hasta ahora nunca ha sido presentado, de manera sistemática, el hecho de que contiene un gran atractivo y puede considerarse como una hermosa obra de arte, a pesar de su brevedad. Viene de la boca del mayor de los orantes y de un inspiradísimo poeta, no cabe duda que el puesto de Jesús de Nazaret está entre los poetas. Mi intención consiste en valorar el Padrenuestro desde dos sobresalientes aspectos: arte y belleza, dejando a un lado las dimensiones teológicas, cristológicas y antropológicas, que ya han sido suficientemente estudiadas a lo largo de la historia de la teología cristiana. De esta manera podemos abordar todavía mejor no solo la calidad sino también la dimensión artística inherente a un texto, que para los cristianos está entre lo más sagrado de su legado espiritual.

Palabras clave: Padrenuestro, oración, arte, belleza, legado espiritual. 
Summary: The Lord's Prayer is the perfect summary of the Christian life and can be considered as its best prayer. It is surprising how easily it has been learned and prayed for by all believing generations, due to the intrinsic values that exist in its simple but deep content. Until now, the fact that it contains great appeal and can be regarded as a beautiful work of art, despite its brevity, has never been systematically presented. It comes from the lips of the greatest prayerful person and from a most inspired poet, there is no doubt that the position of Jesus of Nazareth is among poets. My intention is to value the Lord's Prayer from two outstanding aspects: art and beauty, leaving aside the theological, Christological and anthropological dimensions, which have already been sufficiently studied throughout the history of Christian theology. In this way we can address even better not only the quality but also the artistic dimension inherent in a text, which for Christians is among the most sacred of their spiritual legacy.

Keywords: Our Father, prayer, art, beauty, spiritual legacy.

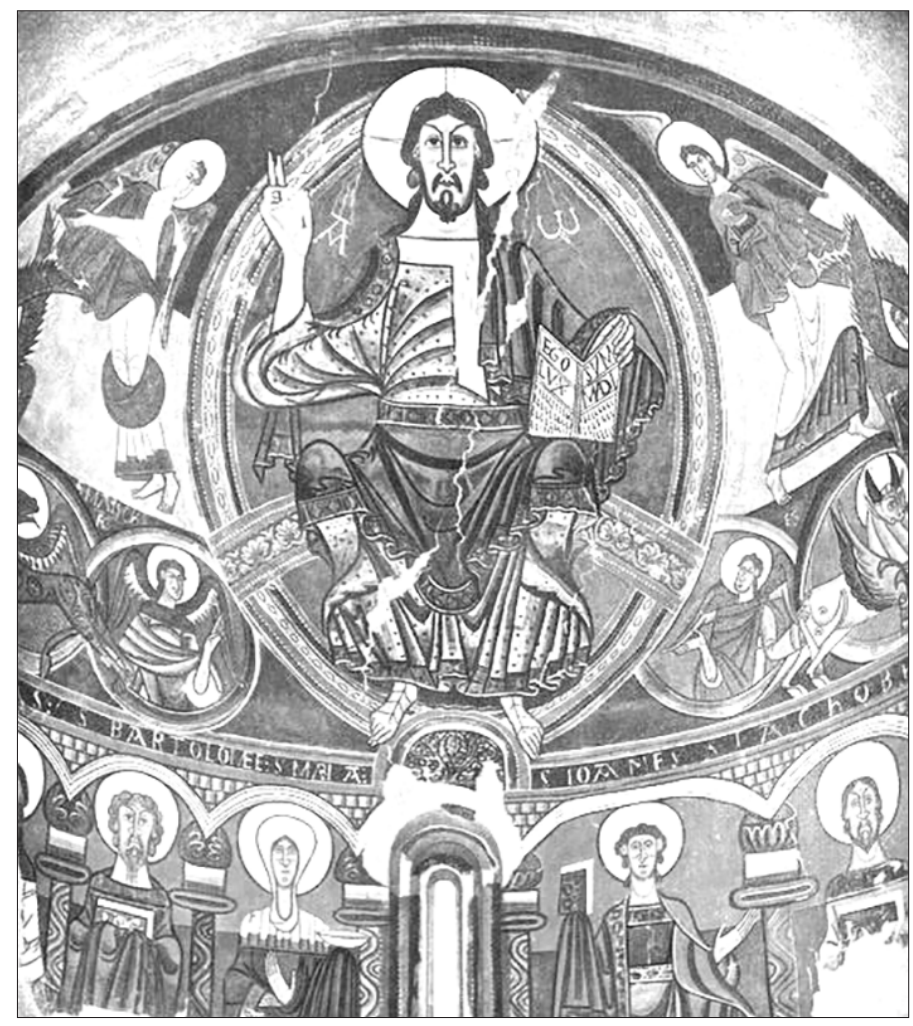




\section{EXPLICACIÓN DE LA IMAGEN}

El día 23 de diciembre de 2016 pasé un buen rato contemplando extasiado una de las obras cumbres del románico del siglo XII, el famoso Pantocrátor de San Clemente de Taüll, que brilla con admirable esplendor en el barcelonés Museo Nacional de Arte de Cataluña (MNAC), nuevamente remodelado. Durante el 17.11.16 hasta el 26.02.17 en la misma estancia pudieron contemplarse también, junto al muro de la parte derecha del Pantocrátor, desgarradoras crucifixiones de Picasso, prestadas por el Musée nacional Picasso-París, flanqueadas por un impresionante grupo de esculturas de Santa María de Taüll, que representan el Descendimiento de Jesús con la expresión de dolor de su bendita Madre, inmovilizada por la pena, y de José de Arimatea, que está abrazado a su Señor en el intento de descenderlo del patíbulo. Ha desaparecido la cruz y uno de los ladrones no tiene brazos, ya que el grupo del siglo XII se encuentra muy dañado. También han desaparecido el Discípulo Amado y Nicodemo, dos personalidades especialmente significativas en el Cuarto Evangelio.

Estando envuelto en tanta belleza, me vino de repente el pensamiento de que ese Cristo glorioso, que nos mira con sus llamativos ojos, no solo es el Creador, Sostenedor y Señor del universo, que sacó a las cosas y a las personas de las tinieblas del no ser a la luz del ser, y dirige la realidad toda con su providencia amorosa..., ese Cristo todopoderoso y glorioso se acredita del mismo modo como el Jesús de la Tierra Santa, que pasó por la vida haciendo el bien (Hech 10,38) y se mostró de una manera muy especial, como el Maestro de oración. Nos enseña el Padrenuestro (desde ahora PN), esa singular plegaria, única entre todas las demás, que nos sitúa entre el cielo y la tierra. Entronizado, nos mira, para que nosotros lo miremos. ¡Sus ojos me miran con amor de predilección, para que yo lo contemple de la misma manera! Abre sus labios, buscando que cada uno de nosotros los abramos. Reza su plegaria en comunión con cada uno de nosotros. Desea compartir contigo y conmigo el encuentro con el Padre, que inunda de gozo cuanto somos y hacemos.

\section{«Yo soy la luz del mundo», el Alfa y Omega}

Nada mejor entonces para mostrar imágenes, que nos ayuden a captar la belleza del PN, que empezar con el Cristo Majestad dentro de la 
mandorla de San Clemente de Taüll. Todo confluye hacia su figura grandiosa, que irradia serena energía y resplandece en todo su esplendor, rodeado y separado del resto de la composición. Aparece triunfante como Dios, principio y fin de todas las cosas. Se alza también como Hombre, que anuncia el Evangelio y reza con nosotros la oración por excelencia. La luz, que despide su figura y viene expresada en el libro que sostiene en la mano izquierda, es la luz del Evangelio, predicado a los primeros discípulos y transmitido hasta hoy por sus seguidores. Es la luz que encuentra un punto culminante en esta bendita plegaria, centro del Sermón de la Montaña, del mismo modo que este constituye el centro de la predicación del Maestro de Nazaret. Estamos ante la luz fulgurante que capta lo nuclear de esta plegaria, la luz que se adentra en el corazón mismo del cristianismo: ¡Padre nuestro!

Enseñándonos y testimoniando esta plegaria Cristo se eleva como luz del mundo, que nos pone en contacto con el Abba de los cielos, proporcionando sentido a nuestra vida y contenido a lo que somos y hacemos. Esta impresionante figura nos encara con nuestra situación de hijos del Padre y hermanos de los hombres, que esperan gozosos el Juicio Final, porque es precisamente después de este acontecimiento, cuando en el ámbito de los bienaventurados contemplaremos al Padre cara a cara en comunión con el Hijo por antonomasia, que se ha convertido mediante la Encarnación en nuestro Hermano Mayor con el poder del amor transmitido por el Espíritu.

El Alfa y Omega de la creación, su principio y fin, encuentran su cúspide en el entronizado Pantocrátor, que en su existencia terrena nos legó la oración de las oraciones, el mejor modo de llegar a experimentar la protección amorosa del Padre en compañía de los hermanos. El Pantocrátor está franqueado por la corte celestial, representada por dos ángeles arriba y por dos serafines debajo de su figura majestuosa. Ellos corroboran el mensaje, que sale de la boca de Jesús: Abba nuestro. La invocación nos permite pasar de las tinieblas de la noche al resplandor del día.

En la medida que nos habla de las realidades del cielo: del Padre, de su Nombre, de su Reino, de su Voluntad y las pone en relación con las realidades de la tierra: el pan cotidiano, el perdón de las ofensas, la tentación a resistir, el mal a evitar, se está convirtiendo para nosotros en verdadera «Luz del mundo». No hay mayor grandeza en la inconmesurabilidad del 
cosmos, que lo que expresa la entrañabilidad del PN. Si un pensamiento, como expresó san Juan de la Cruz, vale más que todo el universo, una oración como el PN sobrepasa todo lo creado. Nos eleva a la altura de Dios como hijos amados y en igualdad con los hombres: como hermanos entre los hermanos.

El PN, rezado cada día, nos invita a no olvidarnos nunca de quién es el Padre, meta de todas nuestras aspiraciones y culminación de nuestra entera existencia. También nos insta a no postergar a los hermanos, con los que hacemos camino en nuestra marcha permanente hacia la eternidad. Nos invita del mismo modo a fijar nuestra mirada en el discurrir diario de Jesús, que conformó una vida dichosa de oración y fraternidad. Su oración, divina y humana a la vez, universaliza la realidad existente, ya que estamos llamados a ser hijos y hermanos en una sociedad abierta, que ha de parecerse más a una familia que a un campo de lucha, violencia y egoísmo y que no puede encerrarse en ella misma, sino estar abierta a los problemas que se dan hoy en el mundo.

\section{María y la Iglesia, los apóstoles y los evangelistas}

Los hermanos más importantes los tenemos representados a los pies del Pantocrátor, en la pared del ábside. Sus nombres están escritos en lo alto: María, los apóstoles y los evangelistas. Fue en este círculo donde se escuchó de labios de Jesús la oración del PN por primera vez. Según nos transmite Lucas, «Una vez que estaba Jesús orando en cierto lugar, cuando terminó, uno de los discípulos le dijo: "Señor, enséñanos a orar, como Juan (el Bautista) enseñó a sus discípulos”» (11,1). Y Jesús les entregó el tesoro de su oración preferida. Contemplar la figura de los primeros cristianos significa tanto como escuchar de sus labios la oración recibida de su Señor.

Empezamos con María y san Juan, que ocupan la parte central de los bienaventurados. Al lado de María, situada a la derecha de su Hijo, aparecen san Bartolomé y santo Tomás, quedando fuera de la representación del fresco otros dos apóstoles, que podemos imaginar, pero que han desaparecido de la pintura. Al lado izquierdo, junto a san Juan, se encuentra su hermano Santiago y san Felipe. Destacan dos cosas en san Juan: la amplitud de espacio dedicado a su figura y el Evangelio mostrado en lo alto, sostenido en la mano derecha, que se esconde debajo de los pliegues de la túnica. Lo que importa ahora son las palabras de Jesús, quedando más 
destacadas de este modo. No deja de sorprender también la Madre de Jesús, que sostiene un platillo en su mano izquierda, escondida bajo los pliegues de su túnica. Muy posiblemente en la persona de María está representada toda la Iglesia, ya que sobresale como su miembro más eminente, que recoge en una apropiada patena la sangre del Redentor, de la que salen los rayos de la salvación. Ella puede rezar la oración del Señor en perfecta representación de la comunidad eclesial entera.

Nos interesa resaltar aquí el acontecimiento de la Cruz y poner énfasis en la palabra del Evangelio, presentes en María-la Iglesia y san Juan, así como del resto de los personajes de primera fila en nuestra religión. Todos ellos transparentan el testimonio de la salvación y de la proclamación del Evangelio, cuyo contenido central se encuentra en el PN. Mirándolos a ellos, nos disponemos a recitar con toda devoción la oración del Señor, que ha dado la vida por cada uno de nosotros. De manera muy especial María y san Juan nos ayudan a expresar gozosamente la reina de las plegarias, acompañados de los coros angélicos, que adoran al Cristo Majestad. Todo ello visible a los ojos de la fe, que hemos adquirido en la Madre Iglesia.

\section{INTRODUCCIÓN}

Hace ya veinte años escribí un comentario al $P N^{1}$. En él consideraba esta oración como «toda una obra de arte». La Editorial Verbo Divino, donde apareció mi estudio, puso esta expresión incluso en la propaganda sobre el libro. Sin duda, a sus publicistas les pareció un «buen gancho» para dar a conocer mi obra y atraer lectores. Pasado un tiempo de reflexión más que prudencial de cuatro lustros, me toca hoy clarificar tal afirmación y, lo que resulta más útil, tratar de justificarla en su misma raíz primigenia.

En esta bendita plegaria Jesús ha querido que sobresalga lo esencial de la oración; en ella aparece lo más básico y necesario, que en realidad sig-

${ }^{1}$ L.Á. Montes Peral, El Padrenuestro. La oración trinitaria de Jesús y los cristianos. Estella (Navarra]) 2000, 206 páginas. Después he escrito otras cosas sobre él, ya que siempre me ha fascinado, volviendo una y otra vez a la Oración del Señor en mis consideraciones teológicas. 
nifica al mismo tiempo lo más urgente, para llegar a la unión íntima con el Padre y congraciarse con los hermanos. Y eso esencial tiene que ver con la Verdad, el Amor y la Belleza, que es el Padre de los cielos y son los hermanos de la tierra. Expresa lo auténtico, por lo que merece la pena vivir, ya que se mueve en las coordinadas de la filiación divina y la fraternidad humana, de modo que su rezo nos ayuda a unir a las personas en una gran familia de hijos y hermanos.

Es bueno que nos vayamos acostumbrando a contemplar la oración y formas del quehacer espiritual como obras de arte y expresión de la belleza en su sentido más genuino. Bonum, verum et pulchrum convertuntur. En realidad, la Bondad, la Verdad y la Belleza se identifican tanto en Dios como en los hombres, cuando se consideran estos tres trascendentales en la debida profundidad y reciprocidad. La oración del PN no solo es bondad y verdad, también belleza en grado sumo. ¿Existe algo más artístico que el Dios Trino y hay realidad más bella que la Santísima Trinidad? ¿Qué puede ser más hermoso que la relación frecuente y permanente con el Padre en el Hijo por el Espíritu? Y ese tesoro se descubre más y más, cuando rezamos el PN.

En mi libro sobre el PN ya he reflexionado sobre la Verdad y el Amor. Ahora quiero detenerme a esclarecer sobre todo la Belleza. La gran Belleza que transmite esta oración y que ha encontrado un buen asiento en miniaturas de códices espléndidos, realizadas por artistas de primer orden, como se mostrarán aquí en la segunda parte. Es una pena que, más allá de formular principios generales, se haya hablado y escrito tan poco en este sentido, de modo que hay toda una calología teológica por hacer. Falta una presentación convincente del Dios Trino como belleza y en su contexto de igual manera del PN, transparencia del Padre, del Hijo y del Espíritu Santo.

Las reflexiones, que se van a ir sucediendo a continuación, no pretenden quedarse en el pasado, estancar la memoria hasta convertirla en un fósil. Más bien desean abrirnos al presente, al hoy de la existencia personal, al aquí y ahora que estamos viviendo. La belleza del PN abarca tanto el pasado como el presente en su orientación hacia el futuro, un futuro más reconciliado, hermanado y compasivo.

Como toda obra de arte la plegaria del PN necesita ser practicada, en nuestro caso rezada, diariamente sin cesar en su continuidad, siempre intentando no caer en la rutina al orar con ella; ese es su gran peligro: hacerla 
monotonía por falta de experimentada sensibilidad, hasta el punto de ocultar su belleza. Somos urgidos a ser muy conscientes cada día de lo que decimos, pensamos y sentimos. El hombre ha sido creado para practicar la bondad y quedar impresionado por su belleza. De ahí que, cuando el creyente usa esa bondad de manera lúcida, se sienta especialmente atraído por el PN y busca rezarlo con piedad, poniéndolo por obra en la medida de sus posibilidades.

Sin olvidar su contenido teológico, profético y sapiencial, pero no desarrollándolo sino suponiéndolo, este pequeño ensayo quiere incidir una y otra vez y, al mismo tiempo, profundizar en algo que el autor no ha encontrado nunca en los muchos estudios y comentarios que ha leído sobre la oración del Señor: considerar el PN como obra de arte y belleza, que en su sencillez y brevedad puede considerarse como una auténtica obra maestra. Es toda una joya por cualquier lugar que se la considere.

Tal como estoy enfocando el tema, me gustaría adelantar y explicar, al hablar del PN estas cinco palabras: alegría, sencillez, generosidad, familiaridad y conversión, que están muy relacionadas con su contenido.

La primera, alegría: No se menciona directamente esta palabra en la oración del Señor, pero despide una alegría íntima que sale del alma y no necesita ser mencionada en el texto. Hablaré de ella a lo largo de mis consideraciones con relativa frecuencia, ya que la bellez a proporciona entusiasmo y exaltación. Acercarse al PN significa tanto como hablar del gozo que produce. Invocar al Dueño y Señor de todas las cosas: ;Padre!, cuando lo es de verdad y así se reconoce, resulta algo muy grande. ¡Nada más gratificante! Sentirse sus hijos con todo lo que representa esta inmensa dignidad, llena de júbilo por dentro. ¿Qué puede proporcionar una mayor satisfacción? ¿Qué bello para el hijo gozarse de la compañía del Padre y estar dispuesto a expresarle los deseos más íntimos! ¿Puede haber algo más consolador que hacerlo precisamente en la compañía de los hermanos? Este entramado vital es lo que nos sostiene en la alegría y alimenta el regocijo creyente.

La segunda, sencillez: En las peticiones del PN no hay nada que suene a complicado o rebuscado. Todo fluye por sí mismo, sin afectación alguna. Entendemos perfectamente lo que queremos decir a Dios y lo expresamos sin afectación con llaneza, sin engolamiento con sobriedad. Además, lo hacemos directamente, evitando las complicaciones, de la misma manera que un niño pequeño se dirige a su padre en quien confía por completo y con- 
templa lo demás con una mirada de satisfacción. ¡Qué bello poder volvernos a Dios sin necesidad de grandes palabras y reverencias innecesarias, ya que el creyente tiene la seguridad de que va a ser atendido en sus peticiones dirigidas con toda normalidad y naturalidad! Eso es precisamente lo que desea en ese sentirse bien y agusto con tan gratas compañias.

La tercera, generosidad. El Padre es generoso y el orante se hace generoso a su lado, ya que se sitúa en una disposición de recibir y de dar, de sentirse amado y ponerse al servicio de los demás. El orante está seguro de dirigirse a un Padre bondadoso, que satisface sus necesidades y está dispuesto a concederle las cosas que necesita. iQué bello es pedir y saber al mismo tiempo que su petición será atendida en el debido tiempo! La generosidad nos pone del lado del Padre, con ella santificamos su Nombre mediante la fraternidad y nos uninos al Reino que su santa voluntad hace nacer en cada uno, proporcionándonos su crecimiento en nuestro interior y en el de los demás. En nuestra generosidad, que imita la del Padre, entra la preocupación por las cosas materiales necesarias, de tal manera que no falten a nadie, también realidades espirituales, que conforman nuestro ser creyente, como la disposición al perdón que evite los rencores inhumanos, dejarse ayudar en las tentaciones que con frecuencia nos asaltan y pueden echar a perder nuestra vida, así como la disposición para luchar contra el mal, revestido de mil formas.

La cuarta, familiaridad. Pertenece a lo más sagrado de los designios del Padre el formar una familia de hijos y hermanos; algo que está también en lo más hondo de las intenciones de Jesús, que se manifiestan de un modo muy especial en las peticiones del PN. Si nos preguntáramos, para qué vino Jesús a este mundo, quizá la respuesta más certera fuera esta: para formar con los hombres, una familia de hijos y hermanos y presentarla al Padre como ofrenda agradable a sus ojos. ¿No es esto bello? Todas las peticiones de la oración del Señor están orientadas a alcanzar este objetivo, que es singularmente hermoso. Tenerlo en cuenta en la vida personal y comunitaria constituye un inmenso gozo y nos indica qué bella puede ser la vida así orientada. Quien no ha rezado el PN en espíritu y verdad, no ha descubierto aún la belleza de la oración.

La quinta, conversión. El PN nos enseña a estar en el suelo, con los pies en la tierra, en la patria propia de los hermanos; pero al mismo tiempo nos eleva al cielo, a poner el corazón en el Padre, principio y fin de la ver- 
dadera realidad. Y así va transformando la propia interioridad, hasta el punto de cambiar nuestra actitud ante la vida. Nos lleva a la conversión en las direcciones más impactantes de la propia existencia. Tiene un valor añadido, que no podemos olvidar: es capaz de removernos por dentro, de manera que aclare nuestros pensamientos, limpie nuestros sentimientos y fortalezca nuestro comportamiento. ¿No es esto belleza transformadora con su lenguaje directo y su expresión sincera?

He aquí mi deseo intimo: que todos reconozcamos la hermosura que el Padre por el Espíritu nos ha regalado en Jesucristo (cf. 1 Cor 2,12). Al mismo tiempo que nos gocemos de la bondad del Padre, que el Hijo humanado nos ha testimoniado en su oración; oración sin igual, que nos ayuda a ser de verdad nosotros mismos, considerándonos como miembros de pleno derecho pertenecientes a una familia singular, que sienten la belleza interior que anima su ser y quehacer en este mundo.

Quiero resaltar una consideración final: Todo esto resultaría imposible llevarlo a cabo sin la presencia y actuación del Espíritu. Son esa presencia y esa actuación las que nos llevan al Padre, al Hijo y a los hermanos, las que nos regalan el fruto sazonado de la alegría y nos introducen de lleno en la belleza del PN. La belleza, como el amor y la verdad, hay que cuidarlos, mimarlos y alimentarlos. El PN no puede considerarse la flor de un día, sino una oración constante, de toda la vida. Es entonces cuando se saca todo su fruto.

\title{
Primera PARTE: \\ EL PADRE NUESTRO COMO BELLEZA
}

\section{LA ORACIÓN BELLA POR ANTONOMASIA}

\author{
Padre nuestro, que estás en el cielo, \\ santificado sea tu Nombre; \\ venga a nosotros tu Reino; \\ hágase tu voluntad en la tierra como en el cielo. \\ Danos hoy nuestro pan de cada día; \\ perdona nuestras ofensas, como también nosotros perdonamos
}




\section{a los que nos ofenden; no nos dejes caer en la tentación, y líbranos del mal.}

Desde un principio hay que dejar claro que la oración del Señor ofrece un indiscutible carácter religioso. No hay nada más ajeno a la verdad que encierra, que despojarla de su significación trascendente y privarla de su más genuina belleza, que enraiza con el mensaje que transmite acerca del Padre del cielo y de los hermanos de la tierra. Al primero mencionándolo explícitamente, a los segundos permaneciendo al amparo del Padre sin llegar a ser mentados. Transpasando la superficialidad, que agosta la vida interior, haciendo a esta incapaz para descubrir lo auténticamente bello, rebasando la incertidumbre de una vida sin sentido, el PN constata que el hombre posee gran capacidad de trascendencia, se eleva sobre sí mismo y en esa superación permanente se encuentra con el Dios Trino, que en Jesucristo es donación y amor incondicional por inspiración del Espíritu. ¿No despide este convencimiento una gran belleza?

Para el músico y dirigente Christian Thielemann «sin trascendencia no es posible ningún arte»; y añadiría: sin trascendencia la belleza se evapora, se le cortan las alas para poder ascender a las alturas, hacia donde siempre se dirige para poder percibirla en todo su esplendor. Esto que podemos afirmarlo de una manera general, vale mucho más para la oración del PN. Las posibilidades del ser humano son finitas, pero no tienen límites y en ese romper límites enraiza el PN con sus ruegos que traspasan la realidad dada.

En este sentido el PN contiene una extraordinaria posibilidad artística y una evocación poética para situarnos de lleno en la ultimidad de la comunión con el Padre de los cielos y en la intimidad de relación con los hermanos de la tierra. Logra hablarnos de las grandes realidades mayores, que importan de verdad en la andadura de cada día y al mismo tiempo nos ayuda a reflexionar sobre nuestro puesto ante Dios, ante los demás y ante el mundo que nos toca modelar. Walter Kasper presenta el PN como «la revolución de Jesús» y en realidad podemos considerarla de este modo. Bien interpretado transforma la imagen de Dios y del hombre, la comprensión de la religión, así como la visión de la sociedad y hasta del mundo. Todo a la vez y todo en una síntesis hondamente bella en medio 
de un variado universo real y simbólico. Su belleza poética resulta tan sublime, que alcanza el centro mismo de la existencia humana y resume la vida cristiana.

El PN, la oración personal por antonomasia, y al mismo tiempo profundamente familiar, nos ayuda a pasar de la tristeza a la alegría, de la duda a la certeza mediante la vivencia gozosa de la filiación y la fraternidad, las dos experiencias centrales de la vida humana y cristiana. Esta oración busca al hombre allí donde en realidad se encuentra o se puede encontrar: en el interior de su existencia más íntima, en sus vínculos permanentes con los Otros y los otros como ser comunitario y en sus contactos básicos con la realidad que le circunda. Si la incertidumbre puede considerarse como la característica más destacada de la postmodernidad, agravada ahora con la pandemia del coronavirus, el PN orienta hacia lo seguro: lo que nos hace realmente humanos en nuestra relación con los demás y lo que nos convierte en divinos en nuestra conmunión con el Dios Trino.

Además, nos ayuda a vivir la vida allí donde merece la pena vivirse y confrontarse con los otros. No se queda en lo anecdótico, superficial e instrascendente, va a lo nuclear, a lo crucial de la existencia cotidiana. De ahí que tantos hayan rezado y recen esta plegaria, para encontrar sentido a lo que son y hacen; para orientarse hacia el norte mismo de lo que significa su ser en este mundo y bregar en la sociedad.

Bien pensado, el PN es lo que cada uno reza en y con Cristo, lo que le posiciona ante el misterio divino y ante la verdad humana. Cualquiera puede constatar esta experiencia: el PN me hace feliz, me hace mejor persona, al relacionarme con Dios Padre, que me orienta más positivamente hacia los semejantes. Orarlo con el corazón rebosante de júbilo en la comunidad de los creyentes confiere confianza y proporciona seguridad. Merece la pena rezar con los otros cristianos la plegaria del Señor, porque nos hace bien, nada más que bien, siempre bien. ¡Ojalá lo hagamos con las mismas intenciones de Jesús en comunión con la fe de la Iglesia!

El PN se mueve entre la humanidad ya hecha y una humanidad por hacer. El orante conoce hasta dónde llega Jesús y hasta dónde puede llegar él, siempre con la ayuda de la gracia; cómo somos nosotros con el rezo de esta plegaria y cómo seríamos, si no existiera o no la conociéramos. Su contenido espiritual y humano no se agota nunca, siempre va más allá, porque tiene capacidad de trascenderse. Por eso lo que ofrezco aquí ahora 
tiene una clara intencionalidad, que importa interiorizar en la hondura del alma: El PN puede revitalizarse, cuando se descubre el arte que contiene en sí y se deja traslucir la belleza que encierra, que es mucha a pesar de su brevedad. Un aspecto más de ese ir siempre más allá en el intento de dar con el sentido de esta oración inabarcable en su contenido.

De lo dicho podemos deducir que la belleza del PN consiste esencialmente en el esplendor de la verdad que transmite. De hecho, constituye el germen de la verdad de las demás plegarias, que siempre despiden destellos de belleza. ¿Qué puede haber más hermoso y hasta fascinante, que la salida del hombre hacia la trascendencia, al escuchar la llamada del Padre; que puede satisfacerle más que implicarse en el encuentro con el Padre mediante la mediación del Hijo? Del árbol frondoso del PN, rezado con frecuencia por todas las generaciones cristianas, crecen y se diversifican las demás oraciones. Su aroma despide un suave olor, que consiste en desarrollar más y más la relación con el Dios Trino en sentida cercanía con los hermanos. La belleza tiene sus reglas, que se entrecruzan e intercambian en la oración del PN.

Durante toda la Edad Media, en todos los países y regiones el PN se recitaba en latín, incluso por la gente sin educación y hasta de dudosa conducta. Todos lo sabían de memoria y conocía perfectamente su contenido. Por eso era conocido comúnmente como el Pater noster y se aplicaba a toda clase de actos de piedad de la religiosidad popular. Se recitaba en los momentos de peligro y cuando se deseaba ardientamente que algo ocurriera. Lo que indirectamente nos está señalando su singular belleza, al alcance de cualquiera en tiempos tanto fáciles como difíciles, poniendo de manifiesto cómo puede juntarse con otros muchos deseos concretos, que nacen del corazón de los cristianos.

\section{A LA BÚSQUEDA DE LA VERDAD Y LA BELLEZA}

He señalado ya la firme convicción de que la llamada «oración del Señor» tiene que ver no solo con la espiritualidad y la teología, también con el arte y la belleza. Considerada debidamente, la verdadera teología desprende belleza y puede ser expresada de forma bella. Qué pena que este hecho indiscutible no aparezca más resaltado en las obras teológicas. 
En el PN tenemos la más alta expresión de lo indicado, en la medida que Jesús, que ocupa un puesto muy alto entre los poetas, se dirige a Dios de la forma que lo hace y nos presenta su realidad de manera sublimemente hermosa. Pero más que hablar sobre el Padre, habla al Padre y con el Padre. Se verifica un diálogo de los hijos con el Padre, o mejor expresado, del Padre con sus hijos

Aunque el olvido de Dios, el eclipse de la Trinidad constituya una de las características más preocupantes de nuestra época, el verdadero hogar y la patria definitiva de los hombres es el Padre, solo el Padre, nada más que el Padre. Los otros hogares, las demás patrias pasan irremisiblemente, no tienen entidad propia y consistencia permanentes. El tiempo de captar la belleza dimana de Dios Trino, que es Padre, Hijo y Espíritu; depende también del hombre, imagen e hijo del Padre en el Hijo por el Espíritu. El PN se ha vuelto para los orantes en un recinto íntimo existencial de vida, en el que puede captar la hermosura divina junto con la belleza humana. A ese círculo virtuoso volvemos, siempre que lo recitamos, como a nuestra propia casa de oración, a nuestra experiencia de alegría y belleza, que se vuelven propias para cada uno de los orantes.

\subsection{La bella buena noticia del PN}

Quiero expresar este convencimiento íntimo: No hay belleza sin el espíritu que la contempla. No hay posibilidad de contemplar la belleza del PN sin el Espíritu del Padre y del Hijo, que viene en ayuda de nuestro espíritu, impresiona nuestros ojos y sobre todo transforma nuestro corazón, para acoger la buena noticia como se debe. El Espíritu creativo, que hace nuevo todo, es capaz de renovar nuestra mirada y de abrirnos el interior a la novedad de la belleza, que desprende la oración del Señor. Entiende la belleza quien vive la experiencia cristiana y esta resulta posible, cuando existe apertura al Espíritu. Detrás de lo expresado en la relación existente entre la Trinidad y el hombre y entre el hombre y la Trinidad, como se desprende del PN, existe toda una obra de arte oculta, que solo puede descubrirse en todo su encanto, cuando se conoce con la ayuda del Espíritu los sentimientos de Jesús, su iniciador y los de cada uno de los orantes, unidos a su Señor por la $f e$, cuando recitan esta oración sin parangón.

El PN restituye a los creyentes su verdad por medio del lenguaje orante y la expresión bella. Realza la vida en lo que tiene de más valioso y sagrado: 
en la acogida de la paternidad y de la filiación en mutua complementariedad. Reta a la experiencia del hombre interior, que trasciende hacia el asombro, la paz y la benignidad que es un fruto del Espíritu. Se sitúa en el centro mismo de la vida y vive en el esplendor de la belleza. El Padre es simpatía en su Hijo. Está al lado de cada uno de nosotros. En su amor se adelanta para acompañarnos. Cura y venda nuestras heridas, para que podamos crecer en la fraternidad, rechazar la mentira y sacar fuera el egoísmo, que en ocasiones nos atenaza. ¿No nos proporciona consuelo tanta belleza?

El PN nos comunica esta bella buena noticia: Podemos participar de la vida divina y podemos hacerlo con todas las garantías de verdad, bondad y belleza. Con su oración Cristo nos ha abierto la relación con el Altísimo. Su Encarnación y Resurrección, su vida entera en la Tierra Santa nos ha mostrado que resulta factible experimentar a Dios y este constituye el objetivo supremo de toda oración, que se precie. Lo verdaderamente hermoso del PN consiste en que nos permite contemplar y vivenciar lo esencial con muy pocas palabras; las suficientes para caer en la cuenta de lo que constituye la causa de Dios y la causa de los hombres.

Quien reza el PN respira lo divino y lo humano, no saliéndose de lo crucial existente en ellos. Se pone en contacto con lo durarero, lo que siempre permanece. Con lo que importa de verdad para orientar la propia vida personal y la comunitaria hacia la felicidad experimentable aquí en esta vida, en preparación de la otra. Por los valores que encierra, el PN se ha rezado en el pasado, se reza en el momento presente y se rezará en el futuro. Siempre estará unido en el tiempo, en lo que tiene de vinculación del hombre con su Creador y Padre.

\subsection{Una objeción que conviene responder}

El PN es una oración breve, muy breve. Consta de muy pocas palabras. Con la doxología de la Didajé registra 68 palabras (incluyendo artículos, preposiciones y conjunciones). En este momento la versión castellana oficial, que sigue la edición ampliada de Mateo, tiene 56 palabras y con la doxología 69 (una palabra más que la versión griega). El original arameo, al que se atiene más la version de Lucas, posiblemente constaría en su totalidad de unas 23 palabras. ¡Solo 23 palabras! Corresponde perfectamente al más íntimo deseo de Jesús, expresado inmediatamente antes de rezar el PN por primera vez: 
«Y al orar, no os perdáis en palabras como hacen los paganos, creyendo que Dios los va a escuchar por hablar mucho. No seáis como ellos, pues ya sabe vuestro Padre lo que necesitáis antes de que vosotros se lo pidáis» (Mt 6,7-8).

Ante este hecho inscuestionable podemos objetar lo siguiente: ¿Puede una fórmula tan breve considerarse como una obra de arte? ¿No estamos exagerando por tratarse de palabras de Jesús? Rotundamente sí se trata de una verdadera obra de arte, aunque sea tan breve su contenido. Qué duda cabe que la extensión de un texto en muchas ocasiones tiene su importancia. Pero lo decisivo para la obra de arte está en la forma, la expresión y la precisión con que aborda el tema expuesto y sobre todo el contenido como tal.

En este sentido el PN acierta de modo bien singular. No se anda por las ramas, perdiéndose en palabras huecas, se centra en lo verdaderamente crucial de la relación con la Trinidad y con los hombres y lo hace con trazos precisos y definitivos, que esconden un mundo interior de reconocida riqueza y espléndida belleza. Deja a un lado la palabrería, que ensucia el espíritu de la oración, para concentrarse en la palabra primegenia: Padre y en las palabras claves del encuentro del Dios Trino con el hombre: su Nombre, su Reino, su Voluntad y de los hombres con Dios: el pan, el perdón, la tentación, el mal. La grandeza del lenguaje está en la brevedad, cuando acierta a expresar lo auténticamente esencial.

El que se haya convertido en la oración más rezada de todos los tiempos, se debe a la maravillosa convicción y verdad, con que nos habla de Dios y a la eficacia y contundencia con que llega al corazón humano. No necesita grandes reflexiones. Se aprende de memoria con facilidad. Así lo demuestran las innumerables generaciones, que lo han recitado una y otra vez desde la niñez hasta la vejez. Se trata de una oración que «da en el clavo», como ninguna otra, y lo consigue hacer de forma tan bella - las personas tenemos una propensión natural para la belleza, aunque no sepamos formularla - que enseguida penetra en la conciencia, siendo fácilmente recordada, agradecida y alabada. Solo Jesús ha logrado con tanta brevedad dar con una formulación definitiva en lo referente a lo esencial de la oración, de los que quieren ser sus discípulos. Pero también de todos los hombres de buena voluntad que desean relacionarse con la Trinidad en espíritu y verdad, incluyendo en esa relación a los hombres hermanos. 
La fascinación del PN estriba en que nos da a conocer no solo el nombre del Padre, también nos lleva a entender lo que resulta más característico de su persona. Consigue adentrarnos en lo que tiene que ser nuestra verdadera relación con el Todopoderoso, que muestra su omnipotencia en el amor. Podemos mantener con el Dios Trino un diálogo vivo y sentido, considerar sus cosas, pero también hablarle con toda la naturalidad de las nuestras, incluidas las necesidades materiales, de las que no debemos avergonzarnos. Decisivo es comprobar en esa relación, que el amor trinitario nos sostiene, alienta y confiere el incremento debido para vivir como hijos y hermanos en filiación y fraternidad, siempre guiados por la mano bondadosa del Padre celestial, que es el protagonista, adelantándonos en bondad, perdón y ternura.

En el PN Jesús, el Hijo Unigénito, nos muestra que en lo más hondo de nuestra existencia no actúa un Ser Supremo frío y distante, sino un Abba cercano y misericordioso, que nunca nos deja abandonados y siempre nos acompaña complacido con su bondad y cariño. Él lo vivió así y así nos lo enseñó y testimonió. En modo alguno podemos considerar al Altísimo y Todopoderoso como un Juez meticuloso y rencoroso, que nos acecha sin cesar para castigar nuestras faltas, sino como un Padre bueno, que acoge a todos, atiende sus necesidades y está dispuesto a amar a la humanidad entera sin restricción alguna. ¿No está esta buena noticia cargada de belleza? El Padre no nos condena de antemano, nos permite entera libertad y está dispuesto a sostenernos una y otra vez en la tentación; no puede considerársele como la causa del mal, sino que nos ayuda con su gracia a vencerlo y superar las pruebas más extremas.

El PN no solo nos habla del Padre a través del Hijo, también en lo profundo está presente y actuante el Espíritu. El soplo del Espíritu vivifica su invocación, así como las siete peticiones de las que consta, según la versión de san Mateo y de cinco según san Lucas. Estamos ante una oración intima, que nunca apaga al Espíritu, más bien lo enciende y mantiene vivo siempre. Desarrolla una espiritualidad de los «ojos abiertos» $\mathrm{y}$ «los pies en el suelo», que nos permite descubrir quién es el Dios Trino y quiénes somos nosotros los hombres en contacto con la realidad en sí misma. El Espíritu abre también a la belleza, ya que el Don del Amor, que le es inherente, se identifica por completo con la Belleza en mayúscula. 


\subsection{La verdad y la belleza del PN}

Para llegar a comprender la realidad teológica tenemos tres caminos complementarios: la via veritatis, fundamento de las demás, la via amoris, ya que la teología no se comprende del todo, sin la puesta en práctica del amor y, por último, la via pulchritudinis, que tiene que ver con la hermosura, que desprende la belleza del amor y la verdad. Verdad, amor y belleza constituyen dimensiones distintas de una misma realidad divina, que se trasciende a sí misma en la expresión de su propio ser y se expresa en una tríada de derivaciones, que en el fondo vienen a desembocar en el mismo mar y a significar lo mismo. Aquí vamos a ensayar sobre todo el último camino, aunque los dos anteriores estén también presentes y actuantes en nuestras consideraciones.

Para ello anticipamos la reflexión siguiente: Alguien ha afirmado que «ars sine scientia nihil est», es decir: «el arte no es nada sin la ciencia». Del mismo modo yo me atrevería a decir, precisando la cuestión: «ars sine veritate nihil est», pero añadiendo al mismo tiempo: «veritas sine arte nihil est». Dicho en román paladino: «el arte no es nada sin la verdad» y «la verdad no es nada sin el arte», ya que ambas realidades se relacionan y complementan mutuamente. Estas constataciones quedan reflejadas, incluso se hacen patentes en el PN, que une de forma espléndida ambas realidades arte y verdad; verdad y arte. Podemos ampliar los conceptos: Teología y belleza se complementan, cuando ambas caminan conjuntamente, dándose la mano e impregnándose en mutua fecundidad y en constatable reciprocidad.

Platón se pregunta en la República: «¿No es verdad que la excelencia de la belleza y la justedad de cada utensilio, ser vivo y actividad no están en relación con ninguna otra cosa más que con el uso para el que han sido hecho o han nacido?». Pues bien, el PN lo pronunció Cristo para orar como Hijo y Hermano en comunión con los hijos y hermanos. Su belleza consiste precisamente en el uso de esta plegaria para aquello para lo que fue creada: para relacionarse con el Padre en el Hijo mediante filiación íntima y una fraternidad universal. Considerado así el PN, y ateniéndonos a aquello para lo que Jesús lo pensó y rezó, nos lleva inexorablemente a encontrarnos con la verdad y la belleza en grado sumo.

El PN constituye el fiel transunto de la verdad y de la belleza en su aspiración suprema. Su verdad conlleva belleza y su belleza consiste en el 
esplendor de su verdad. Manifiesta verdad y belleza no solo en su totalidad, también en todos y en cada uno de sus elementos: en su invocación y en cada una de sus cortas peticiones, de modo que traslucen la imagen exacta de lo divino en la elevación del alma hacia el Señor de la vida y en la relación amorosa con el Padre de los cielos. El rezo libre y consciente, gozoso y esperanzado de esta oración nos permite incluso poseer a la Trinidad mediante el amor, para ponernos, al mismo tiempo, al servicio de los hermanos de acuerdo con la voluntad paterna. Como auténtica construcción religiosa es digna del arte y la belleza, de la verdad y del amor. ¡Qué bello resulta gozarse en estas vivencias, que integran por igual razón y corazón con sus pensamientos y sentimientos!

Alguien ha dicho con toda razón que el mundo occidental ha creado y construido sus obras más bellas desde el espíritu de la religión. El PN, tan repetido una y otra vez en este mundo nuestro, sin duda representa ese espíritu de la religión en grado superlativo. No necesita de muchas palabras, valen y bastan las que tiene por la intensidad de su sencilla exposición y por la emoción de sus evocaciones, así como por la calidad de sus sentimientos en la expresión de la relación mutua. En este sentido el PN alcanza, como obra de arte, a todos los humanos, aunque sin duda haya tenido su expresión más extendida en el ámbito occidental.

\subsection{La oración que resume la vida de Jesús y se acomoda a las comuni- dades creyentes}

El PN resume la vida entera de Jesús: su querer y esperar, sus planes y sus obras, sus postulados e intenciones más íntimas. Pero el Señor no hace teoría sobre la oración con dilatadas disquisiones (Lc 11,1-4). Superando a los grandes profetas que le precedieron, testimonia con el ejemplo su apasionante y apasionada relación con el Padre y los hermanos. Rezando él mismo en compañía de los suyos nos enseña a cada uno de nosotros a orar, ya que el testimonio personal constituye el mejor camino para aprender el convincente trato con el Altísimo.

Una obra de arte no alcanza su objetivo más preciado hasta que no se introduce en el consciente de los destinatarios y los impele a la acción. Y así ocurre con la oración del Señor. Solo la entenderemos bien y podrá cambiar nuestra acción, cuando la recemos con la intención y las actitudes que nos mostró Jesús, el Hijo de Dios y el Hermano de los hombres. 
Cuando adoptemos las mismas actitudes que él tuvo, cuando nos dejemos amar y amemos, como él lo hizo, cuando estemos dispuestos a obrar a la manera que él obró imitando también su estilo de oración.

Con todo, conviene añadir que, aunque los primitivos cristianos en seguida aceptaron el PN como fórmula normativa, pronto lo acomodaron a las necesidades precisas de cada comunidad. Así puede comprobarse en los evangelios de Mateo y Lucas y en el escrito subapostólico de la Didajé, en los que se nos han conservado los textos más primitivos, como anteriormente hemos constatado. Lucas enseña el $\mathrm{PN}$ a paganos, que aún no saben orar. Mateo en cambio lo hace para judíos que ya saben orar, pero pueden hacer mal uso de su oración. La obra de arte contiene aún más destellos de belleza, cuando se puede ajustar a las circunstancias concretas de quienes entran en relación con ella, mejorando su percepción de la realidad y sintiéndose mejores en el uso de sus relaciones personales. Y así sucede en alto grado con esta bendita oración desde sus tiempos más antiguos.

Tanto su invocación como sus peticiones constituyen un verdadero remanso de belleza, que amaina las pasiones, nos proporciona serenidad con nosotros mismos mediante la comunión con Dios, nos compenetra con los demás y nos transmite una paz difícilmente perceptible en otros textos. La filiación y la fraternidad, repetidas y experimentadas hasta la saciedad, marcan la entraña misma de esta plegaria sin par, que cuanto más se reza más destellos de belleza desprende, porque se va comprendiendo mejor lo que significa ser hijo y ser hermano en la realidad trabajosa de cada día. El amor infinito de Abba, que es Padre y Madre en un mismo trazo, desprende comprensión inagotable, perdón incondicional, permanente preocupación por los dolientes, todo de forma insuperable e insosyalable.

Cuando oramos junto con Jesús, vamos descubriendo con inmenso gozo, cómo el Padre de la bondad y la belleza nos va recreando constantemente en el amor, empeñado como está en lograr la definitividad de nuestra existencia. Afirma constantemente nuestro ser y su deseo es que llegue a la plenitud. Eso es lo que espera de nosotros, porque ya nos está proporcionando las gracias necesarias para ello. Siempre permanece a nuestro lado, sin que se aparte de nuestras preocupaciones, obrando únicamente el bien y volcado en mantenernos apartados del mal, con el que no tiene arte ni parte. El PN nos llena, pero a la vez nos vacía. Nos llena 
de bien, de comprensión, de serenidad, de paz y nos libra del egoísmo, del rencor, del desenfreno, de toda forma de maldad. La eficaz presencia del Padre bueno prevalece por encima de cualquier tendencia malsana a la negatividad y evita toda forma de autodestrucción.

Los hombres con demasiada frecuencia hemos hecho de la vida un campo de batalla, lleno de conflictos de toda clase. El PN, rezado en su verdad, logra en nosotros todo lo contrario. Conforme a los planes divinos la existencia humana está llamada a constituirse en un lugar de armonía, en el que no se experimenta la muerte sino la vida, no se busca la crueldad sino la bondad, no lleva a la violencia sino a la paz del alma. Nada tiene que ver con la fealdad de la disgregación sino con la belleza, que encierra la apertura a la comunión con el prójimo. Nos invita a una cotidianidad amable, digna de ser reconocida y agradecida, interpretando el propio ser y quehacer desde la gracia que nos brinda el Padre bueno en beneficio de nuestros hermanos.

Quien ora con esta oración busca la bondad, imitando al Padre, que hace a las personas mejores, a veces incluso sin que ellas mismas tengan conciencia de ello. El orante cristiano, cuando se pone delante la presencia del Padre, sigue al Hijo encarnado y su alma recibe la inspiración y la fuerza del Espíritu, está llamado a crecer en la bondad, en la verdad y en la belleza. El PN no es la más hermosa de nuestras ilusiones, sino la belleza real, la más real, la realísima por encima de todas las demás en la experiencia de nuestra propia interioridad, que nunca engaña.

\subsection{La nobleza del PN, fuera de toda maldad}

Algunos sostienen que «el arte no está destinado a mejorarnos como seres humanos». Craso error, sí está destinado a mejorarnos y el auténtico arte nos hace más humanos. Nada más mentiroso que un arte neutro inexistente o un pseudoarte rastrero, que envilece. El verdadero arte ennoblece y nos hace mejores personas en cada una de sus expresiones. El arte auténtico está al servicio de todo lo que tiene que ver con lo humano en sus múltiples manifestaciones. Embellece aspectos de nuestra existencia que quizá desconocíamos o no habíamos reflexionado sobre ellos suficientemente. Ayuda a superar las contradicciones existentes en la vida, que pueden desviar su sentido auténtico. Consigue diferenciar perfectamente entre el bien y el mal, poniéndose al servicio del primero y luchando 
contra el segundo. En el PN este hecho encuentra una confirmación paradigmática.

Los actos violentos, y más aún los monstruosos, cométanlos quienes los cometan, no pueden ser bellos en sí, son simplemente abyectos y se apartan de cualquier forma de hermosura. ¿Acaso hay belleza en un crimen por bien narrado que esté? El arte puede ser peligroso, pero nunca abyecto. No se da arte en la maldad como tal, aunque sí puede mostrarla y presentarla como lo que es: como algo que hace daño a las personas y las aparta del camino auténtico de la verdadera vida. No hay que dudar que la maldad se identifica con anti-arte. Un arte sin posibilidad de valoración de juicio moral, no deja de ser una entelequia, peor aún: una contradicción en sus términos.

La maldad, aquello que de verdad hace daño a las personas, en realidad no tiene derechos y menos justificación. Perjudica a la humanidad y en todo caso hay que tratar de destruir lo que tiene de malo, siempre que sea posible, usando para ello medios legítimos. La maldad es fealdad y como tal hay que mostrarla, no puede ser camuflada, so pena de degenerar el verdadero arte, instrumentalizándolo para fines espúreos. Esto no quiere decir que haya una maldad terrena absoluta y que en ocasiones solo y únicamente se muestre como tal. Siempre pueden apreciarse destellos de bondad en ella y, por lo tanto, despide cierta hermosura y no poca atracción, que conviene distinguir debidamente de la maldad como tal. Como el trigo y la cizaña de la parábola de Jesús, también la maldad se mezcla con la bondad. Constituye un empeño nuestro saber distinguirla, valorarla, discernirla, juzgarla, llamarla por su nombre y desenmascararla como se merece, para que no se presente como lo que no es.

Ejemplarizar el mal, y lo que aún es peor, presentarlo como bello, pone de manifiesto cierta fibra ética, que existe en las sociedades occidentales y en algunos de sus artistas, que se empeñan por cambiar el recto orden de las cosas y piensan que con sus provocaciones pueden considerarse vanguardistas. El bien favorece el progreso, el mal lo entorpece. Aunque se dan opiniones en otro sentido, el mal, que en algunas de sus formas tanto fascina en la actualidad, hay que rechazarlo como antihumano y pedir al Padre que nos libere de su hechizo. Lo que suplica ante el Padre la última petición del PN: «líbranos del mal» tiene pleno sentido en todas las manifestaciones de la existencia, también en el arte. 
El PN nos invita a permanecer en el Bien (Rom 12,9), donde anida el esplendor de la Belleza. Hay que resistir al Mal, que produce odio, violencia, destrucción y fealdad, por mucho que se pretenda afirmar lo contrario. ¿Qué es el Bien? ¿Qué es el Mal? No se trata de dar definiciones, que nos llevaría a incontables disputas. Podemos conocer uno y otro por las consecuencias que dejan y por los efectos que despiden. «Por sus frutos los conoceréis» (Mt 7,20). Y el PN deja unos frutos inmejorables en los orantes.

\section{SIGUIENDO LOS PASOS DE LA POESÍA HEBREA Y TRAS- PASÁNDOLOS}

En el PN encontramos una forma suprema de poesía, que sorprende por su concreción y muestra admirable maestría. Poesía que nos ha dado como gracia el Hijo de Dios, algo que no conviene olvidar nunca; y poesía que nos ha traído el que también se acredita como Hermano de los hombres, que al llegar la plenitud de los tiempos quiso asumir la condición humana hasta darnos la prueba definitiva de amor y hacerse uno de los nuestros con todas las consecuencias, al tomar un cuerpo semejante al nuestro y desgastarlo al servicio de la humanidad caída. ¡Qué hermosura la solidaridad del Hijo con los hombres! (cf. 2 Cor 8,9). El PN nos muestra el camino más poético que conocemos, cómo el hombre, a través de la oración, puede encontrarse con Dios, confrontarse con su propio ser y comprometer su quehacer con los semejantes a quienes considera sus hermanos. Se trata de una plegaria, en la que se unen armónicamente la ejemplaridad, la verdad y la belleza. ¡Y esta trayectoria poética se realiza de la mano del Hijo, que «me amó y se entregó por mí»! ( $\mathrm{Gal} 2,20)$.

Desde un principio precisamos constatar que el PN respira el espíritu del Primer Testamento. En él encontramos algunos pensamientos que casi están contenidos al pie de la letra en los libros más recientes de la Sagrada Escritura. Pero Jesús no cita literalmente a ninguno de ellos, aunque los tiene en el trasfondo, como no podía ser de otra manera. Del mismo modo se mueve dentro de la fecunda corriente espiritual de los profetas, los piadosos anawim y de los sabios de Israel, porque en ellos tiene sus raíces y bebe de su savia fecunda. Ha sabido recoger lo más valioso de la oración, 
no porque lo haya copiado sino porque ha hecho experiencia propia, lo que en realidad supone un auténtico trato con el Altísimo en plena comunión con su pueblo.

Esto no reduce, ni mucho menos, su originalidad, ya que el PN $-\mathrm{y}$ así lo han considerado siempre los comentaristas - puede entenderse como plena creación suya, genuina expresión de su rico mundo interior, que desea manifestarse en el exterior mediante un atractivo ejemplo de experiencia íntima y compromiso espiritual. En este sentido ofrecen orientación propia: la forma conferida a la composición, la precisa elección de las súplicas, el orden en que coloca los temas, la cortedad, pero al mismo tiempo, la concreción con que expresa lo esencial, la variedad de los motivos que animan el conjunto y, por último, la cerrada unidad que conforma la totalidad de lo formulado.

El verdadero artista no flota en el aire, tiene sus pies en la tierra de sus mayores, bebe de sus fuentes y sabe recoger con fidelidad lo mejor de la tradición conforme a su visión específica, fecundando así el conjunto presentado con su propio genio poético, en el que tiene que ver mucho la inspiración del Espíritu (Sería bueno tratar la relación con el Espíritu en la expresión del arte jesuádico, pero derivaríamos hacia una dirección que merece ser abordada como tema propio). Con todo el verdadero artista, como en el caso de Jesús, también se muestra creativo, elevando los temas ofrecidos a algo aún no expresado con anterioridad. Lo que hace del PN una oración tan llamativamente judía, pero al mismo tiempo tan universal, está precisamente en la concreta exposición de los motivos, que son propios de cada hombre, alcanzando de lleno la sustancia de la condición humana.

Y ahora, después de estas observaciones preliminares, desmenucemos de manera precisa el talento artístico de Jesús.

\subsection{En la esencia de la poesía}

Si poesía consiste en captar, y expresar a su vez, la hondura de la realidad con belleza, nuestra oración contiene poesía en superlativo, como muy pocos textos. Capta la grandeza de Dios y la dignidad del hombre en unos términos precisos nunca antes desarrollados hasta el día bendito en que Jesús los expuso. Dios se alza como Padre, Santo por encima de toda ponderación, realizador del Reino del amor y de la paz, de la verdad y la 
justicia, y como consumador ante el mundo de sus designios de salvación. Desea que de la misma manera que Él quiere a los hombres, así se amen los creyentes mutuamente con la marca de la bendición divina. Se preocupa de las necesidades humanas y las atiende con providente solicitud.

El hombre, por su parte, encuentra en Dios la llave para dar con el sentido de la vida y para hacer posible el logro de la existencia en múltiples de sus manifestaciones. Como ser necesitado, eleva su súplica al Altísimo, alcanzando para su bien lo más íntimo de la identidad divina: comportarse como un Padre amoroso con los humanos, llamados a ser hijos y hermanos en el Hijo Unigénito y el Hermano Mayor. Insiste humildemente que no le falte nunca la gracia que sale de sus manos para no caer en la tentación y, con su omnipotencia, que le libre de todas las diversas formas del mal existentes en el mundo.

Si esto es así, ¿no descubre entonces el PN lo más íntimo del ser de Dios y del hombre, que hemos podido alcanzar los mortales y que nos basta para llevar una existencia dichosa a pesar de las pequeñas o grandes preocupaciones y penalidades cotidianas? ¿No desprende belleza por doquier esta oración en el esfuerzo humano por dirigirse a su Señor conforme los dictados expresados por su Cristo? En el itinerario del alma hacia su Creador, la aventura más sublime que puede acometer el hombre, ¿ha encontrado alguien una plegaria más precisa y condensada, más real y consoladora que recoja con tanta maestría la expresion última de una depurada religiosidad, llamada a ser testimoniada personalmente en medio de la comunidad en la que habita el Espíritu e inspira sus mejores realizaciones?

\subsection{En los secretos de la poesía hebrea}

El PN sigue los cánones de la poesía hebrea. Hoy día damos por seguro que el original griego, que ahora poseemos en dos versiones complementarias, recoge y traduce con fidelidad las palabras arameas, salidas de la boca de Jesús orante. La intención primera y última que trasluce el PN tiene una evidente raíz jesuádica que no podemos olvidar nunca, ya que constituye el punto de partida de toda reflexión sobre el particular. Por eso, estamos ante la oración judía del rabino de Nazaret que, en comunión con la espiritualidad de su pueblo, supo penetrar en lo profundo y sensible de la naturaleza humana, para descubrir la presencia divina y 
transmitirnos a través de ella enseñanzas relevantes acerca del Dios Trino de la vida y del amor.

Lo hizo entonces ante sus discípulos de la primera hora y en ellos lo hace también ahora ante cada uno de nosotros. La oración, que en su día rezó con sus seguidores por los caminos de Galilea, la reza en cada momento con la comunidad de los creyentes reunida en la mesa de la Eucaristía, en otras celebraciones de los cristianos, en las expresiones creyentes de las familias y hasta en las plazas del mundo. Tenemos para siempre su promesa: «Cuando dos o tres estéis reunidos en mi nombre, allí estoy yo en medio de vosotros» (Mt 18,20). Algo que suena a verdad, sobre todo cuando el rezo del PN sube hasta el Padre de los cielos.

La poesía hebrea, tal como aparece en su forma más característica, en el Libro de los Salmos, se rige por el llamado «paralelismo de los miembros» (parallelismus membrorum). En el PN encontramos también ese procedimiento poético, tan querido para los judíos. La primera parte del paralelismo contiene las llamadas «peticiones tú», la segunda «las peticiones nosotros». Unas y otras expresadas mediante el correspondiente pronombre personal. En la versión aramea aparece muy remarcado el ritmo oriental y la rima final. La primera parte, la relativa a las peticiones tú, viene caracterizada por la rima -eka. La segunda, la relacionada con las peticiones nosotros, por la rima -enu.

El paralelismo adquiere proporciones perfectas. Las «peticiones tú» representan la causa de Dios, lo que el Padre, en su calidad de Padre, desde siempre realiza en favor de los humanos desde la consideración de su Nombre, su Reino y su Voluntad. Las «peticiones nosotros» descubren las necesidades humanas, empezando por los materiales, y concluyendo con las más espirituales. Ambas realidades se armonizan plenamente. La causa de Dios verifica su verdad en la disposición divina, dirigida a favor de los humanos. Y los hombres, alzan su voz ante Aquel que les ayuda en las urgencias surgidas en el quehacer diario.

Conforme a estos postulados, los deseos divinos pasan a convertirse en proyectos de amor para con los hombres y en misión a cumplir. Y las necesidades humanas son escuchadas por un Padre bueno, que llama tanto a la filiación como a la fraternidad. El PN puede considerarse entonces como un breve salmo de súplica, dirigido al Dios universal judío, que ha dejado de llamarse Yahvé, para convertirse con todas las garantías de ver- 
dad, en el Padre de nuestro Señor Jesucristo, abierto a la salvación universal de todos los hombres, y a quien desde ese momento no queda más remedio que invocarlo como Padre, la primera y más valiosa de las revelaciones del Nazareno, el Hijo Unigénito humanado.

Pero se trata de una súplica, en la que implícitamente está contenida la alabanza y la acción de gracias. Algunos han encontrado extraño que ambas no estén consignadas expresamente. Pero en esto consiste precisamente el arte: en saber adivinar lo que puede esconderse detrás de las palabras y de los giros empleados. En saber identificar las emociones y actitudes que pasan por el orante, algo que captan perfectamente los orientales, pero que nos resultan más difíciles de adivinar a los occidentales. Y la alabanza y la acción de gracias constituyen sin duda el secreto mejor guardado que esconde nuestra oración, pero que con la ayuda del Espíritu podemos descubrir en medio de una inmensa alegría.

En primer lugar, la alabanza. Reconocer la santidad del Nombre divino, desear la plena consumación de su Reino, estar dispuesto a cumplir su voluntad, regla suprema del bien obrar, ¿no significa ya alabar lo más grande que el Padre nos ha puesto ante nuestros ojos y nos ha entregado junto con la hermosura de su amor? Estamos ante una alabanza en acción, que va más allá de las simples palabras. Se menciona del Padre lo que más le puede glorificar y ensalzar debido a sus gestas en beneficio de los hombres.

En segundo lugar, la acción de gracias. Cuando me dirijo al Padre y solicito ante su presencia lo necesario para la vida diaria, me acojo al perdón de los pecados propiciado por Él y confío plenamente que me otorgará la fuerza necesaria para vencer la tentación y superar el mal, ¿no se encuentra aquí también el deseo de agradecimiento y sobre todo de acción de gracias, porque estamos seguros que el Padre nos lo va a conceder? Por eso igual que al final del PN profesamos un rotundo ;Amén!, también podíamos añadir un convencido « ¡Deo gratias!». ¡Gracias sean dadas a Dios Padre en el Hijo por el Espíritu!, este agradecimiento se encuentra sin duda en su trasfondo, en lo más sagrado que desea transmitir.

\subsection{Al encuentro de la filiación y la fraternidad en bellísimo equilibrio poético}

Como ya hemos mostrado una y otra vez, la armonía poética del PN bascula entre dos direcciones que guardan una perfecta armonía: una, 
hacia la filiación divina y otra, hacia la fraternidad humana. El orante, que sigue a Jesús en su rezo, se siente hijo del Padre de los cielos y hermanos de los hombres, aquí en la tierra, sin que ambas vertientes se hagan la guerra entre sí. ¡Todo lo contrario! En labios de Jesús filiación y fraternidad se besan, lo mismo que la justificia y la paz en boca del salmista. La filiación entonces no crece a costa de la fraternidad, ni la fraternidad se afirma a espaldas de la filiación o en su contra. El conjunto aparece expresado y vivido en sorprendente equilibrio: avanzar vitalmente en la filiación significa, al mismo tiempo, progresar en la fraternidad. Cuanto más hijos, más hermanos. Cuantos mayores grados de fraternidad se alcanzan, más crece la filiación. Cuanto más hermanos, más hijos.

Siguiendo a la par estas pautas tan divinas y tan humanas, el PN nos consuela con la promesa de que cuanto más crecemos en la divinización, tanto mayor resulta nuestra humanización. Dios y el hombre, cuando penetran en las auténticas relaciones, no ofrecen intereses encontrados, sino semejantes, complementarios, hasta iguales mediante la conjunción de voluntades. El camino de la oración, recorrido por el orante siguiendo el magisterio y el testimonio de Jesús, corresponde por completo al hecho incuestionable de traducirse en perfecta expresión de lo más divino, para al mismo tiempo ser de modo creciente más humano.

Además, nos adelanta el fundamento de toda auténtica oración: crecer en la filiación para alcanzar la humanización y crecer en la humanización para llegar a la divinización. Todo esto, cuando se contempla en su radicalidad, es decir en lo íntimo de su raíz troncal, desprende una singular belleza propia de la dignidad humana y conseguida para beneficio de los hijos y hermanos del Reino. El creyente nunca puede olvidar que solo se puede realizar como hombre con todas sus potencialidades, en su doble dimensión de hijo y hermano, cuando sabe sacar su fuerza de la oración del Señor. ¡Con la ayuda de la gracia puede conseguir lo que pide y tanto desea en su corazón y no le resulta posible alcanzar con sus propias fuerzas únicamente!

Pero la belleza del PN no se muestra de modo independiente con la oración como tal. Bien al contrario, se encuentra en íntima conexión con lo expresado en ella, incluso puesto a su servicio. La poesía se esconde detrás del mensaje y le sirve de vehículo para hacerlo más vivo, hermoso y atractivo, más cargado de verdad y encanto. Por medio de una forma poé- 
tica bien precisa se van expresando pensamientos, emociones, sentimientos, afectos, deseos y tambien preocupaciones, que se encuentran en el centro mismo de la vida diaria, cuando esta se abre a la trascendencia. Por eso el PN suena tan real, consecuente y sincero, $\tan$ concreto en el quehacer cotidiano.

El orante se encuentra ante el Padre, con sus ansias de volverse hacia Aquel que escucha sus urgencias y atiende sus necesidades, surgidas de la interacción en relación con sus semejantes. Al mismo tiempo se acerca a los hermanos. La subjetividad individual queda complementada por una nueva subjetividad colectiva. Importa el «yo» en la medida que se considerada integrado en el «nosotros fraternal». En esa interacción el orante va tomando conciencia por la fe que el Padre se muestra en la comunidad de la Iglesia.

\subsection{Situados en el presente y caminando hacia el futuro}

Fascina la maestría con que el PN integra los tres tiempos de la historia. El pasado, ya que la plegaria dirigida al Padre se hace memoria agradecida en cada orante. La oración sólo resulta posible cuando se reconocen las maravillas obradas por Dios desde los orígenes en la creación y de un modo muy especial en el hombre, con la única creatura terrena con quien puede mantener un diálogo libre, consciente y responsable. La relación parte siempre del hecho de que el Padre conoce nuestras urgencias y sale al paso de ellas antes de que elevemos nuestras súplicas (Mt 6,8). El presente, ya que el PN está motivado por una fantástica confianza, que se verifica aquí y ahora. El orante sincero tiene el pleno convencimiento de que el Padre atiende con solicitud nuestras necesidades, porque desea lo mejor para sus hijos. El plan divino de salvación puede lograrse inexorablemente, siempre que no falte la colaboración humana. Pero llegará un día, en que los designios del Padre no tengan marcha atrás, porque se habrán conseguido plenamente. De ahí que sea muy fuerte la perspectiva de futuro, presente en el orante.

Para él su mayor preocupación está en servir a la nueva familia de Dios, creada con la llegada del Reino que irrumpe con la persona y actuación de Jesús. Importa que el Señor sea el Padre no los hombres, lo que sería la mayor de las imposturas; resulta imprescindible que se cumpla su voluntad, no nuestro capricho; que se imponga su perdón, no nuestra ven- 
ganza; que venza el bien y no nos dejemos arrastrar por el mal. El Padre desea transformar nuestra vida y ahí ha de implicarse con todas sus fuerzas la colaboración del orante, que quiere que ante todo triunfe la soberanía divina, de modo que el plan divino de salvación definitiva llegue cuanto antes y se transforme la realidad en un suelo nuevo y en una tierra renovada.

En este sentido el PN no se estanca en el presente, aunque lo considere con realismo, como hemos mostrado. Se alarga hacia el futuro, buscando que culmine la soberanía paterna, que es luz y verdad, vida y amor. Jesús es consciente de que vivimos los últimos tiempos de la historia ( $Q$ 10,23-24 = Mt 13,16-17/ Lc 10,23-24), caracterizados por la formación de la familia nueva de los hijos y hermanos del Reino, que se dejan guiar por el Espíritu. Pero da un paso más y pone su mirada esperanzada en el futuro final. Por eso, el PN tiene un sentido escátológico, al que todos los comentaristas hacen mención, por constituir una de las características más remarcadas. Vislumbra entonces el final de los finales y lo hace deseable. ¿Puede haber una belleza mayor que orientar a los humanos hacia la esperanza cierta, que llegará a cumplirse por completo cuando la santa voluntad divina se haga en la tierra transformada como se hace en el cielo?

\section{APOYÁNDOSE EN LA TEOLOGÍA DEL PRIMER TESTA- MENTO, Y REBASÁNDOLA}

Las claves presentes en la oración del Señor tienen un evidente enraizamiento judío, como ya hemos mostrado anteriormente. Resulta imposible de entender sin la teología y espiritualidad del Primer Testamento y de sus autores más inspirados. En relación con la forma conviene mencionar el impulso del Libro de los Salmos. En lo relativo a las tres peticiones tú, hechas pensando desde Dios, no queda más remedio que recurrir a Ezequiel (para la primera), a Daniel (para la segunda) y a Isaías (para la tercera). Las cuatro peticiones nosotros tienen que ver con temas sapienciales y apocalípticos del mejor cuño.

En el PN ese Jesús, que bebe de las fuentes bíblicas y tiene su sitio entre los creadores más inspirados, descifra su propio misterio y al mismo tiempo el de los hombres, ofreciendo el auténtico rostro divino y, a la luz 
de su bondad, quiénes en realidad estamos llamados a ser los hombres, descubriéndonos el rostro fraternal. Pero el PN descubre la viveza de la divinización y de la humanización en la experiencia del orante de tal modo que sobrepasa con mucho lo logrado por la espiritualidad judía en su larga historia. El PN transparenta la grandeza y la armonía existentes entre lo divino y lo humano, como nunca de esa forma se había mostrado hasta entonces. Resume la buena noticia de lo que significa ser Dios y ser hombre.

En este sentido traemos aquí unas palabras de Jesús, cuando lleno de la alegría del Espíritu, llama bienaventurados a los que le siguen, escuchan sus palabras y son testigos de sus obras: «iBienaventurados los ojos que ven lo que vosotros véis! Porque os digo que muchos profetas y reyes desearon ver lo que vosotros veis, y no lo vieron; y oír lo que vosotros oís, $y$ no lo oyeron» (Lc 10,23s). Entre lo que los discípulos han oído está la oración del PN.

Quien lo proclama y vive es el Hijo unigénito del Padre y el Hermano Mayor de los hombres como nadie lo ha sido. Quienes pueden rezarlo en su companía son los hijos, llamados a formar una unidad compacta con el Hijo por antonomasia. Pero también son los hermanos, que experimentan la fraternidad, que ya no tendrá marcha atrás, a pesar de las debilidades humanas. ¿Se ha expresado algo tan atrayente, tan sencillo, tan concreto y tan veraz entre Dios y los hombres como la oración salida de labios de Jesús, en la que se constata cómo el Hijo de Dios se hace hombre para hacer de nosotros hijos del Padre con la fuerza del Espíritu?

\subsection{La oración trinitaria por excelencia}

El PN es oración trinitaria por los cuatro costados. El subtítulo de mi mencionado libro es este: «La oración trinitaria de Jesús y los cristianos». La oración trinitaria por excelencia. Sostiene san Cipriano: «¿Qué oración puede ser más espiritual que la que fue enseñada por Cristo, por quién nos fue enviado también el Espíritu Santo? ¿Qué súplica más verdadera ante el Padre, que la que ha salido de la misma boca del Hijo, que es verdad?» y yo añadiría: también es belleza (De dominica oratione 2).

Ponernos a rezar el PN significa tanto como hacer presente aquí y ahora al Padre, al Hijo y al Espíritu Santo, que entran a entablar con el orante un diálogo de amor, en el que están presentes tanto los intereses divinos como las necesidades humanas, que hacen a los hombres más hijos 
y hermanos. La Trinidad se muestra interesada en contruir en nosotros el hombre interior, pero también el exterior, uniendo la filiación con la fraternidad. Ambos resultan necesarios para establecer ese diálogo de amor, que la Trinidad desea ardientemente.

En el PN no hablan las ideas, por bien estructuradas que estén, más bien transmite la gracia del Espíritu, para invocar al Padre y pedir sus dones, los que de verdad hacen más personas a los hombres en comunión con el cielo y la tierra. El Espíritu del Amor, que procede del Padre y del Hijo, va sembrando sus dones de la filación y la fraternidad, para que resplandezca de lleno el gozo de la comunión. La dulzura del amor es capaz de ablandar los corazones duros y afrontar retos para alcanzar metas comunes. El estímulo de la concordia y de la reconciliación posibilita caminar hacia adelante, sostenidos por la mano del Señor, que nos acompaña en la andadura diaria e impulsa nuestras propias realizaciones.

\subsection{Vivir ante la presencia del Padre y de los hermanos}

El PN nos invita a vivir siempre ante la presencia del Altísimo, percibido a la luz de la fe. Ya los salmistas del Primer Testamento habían ansiado llevar «una vida ante el rostro del Señor», incluso buscar su cercanía bienhechora sin interrupción (Sal 26,8; cf. 30,17; 50,13; 68,17). Conformar la existencia ante la presencia del Dios vivo era el gran reto de los piadosos judíos, lo que alentaba su quehacer diario y confería a su actuación el debido sentido. Ese ardiente deseo, que expresaron de mil modos con tanta belleza los sabios, profetas y sacerdotes de Israel se ha hecho realidad gozosa, como nunca lo hubiéramos imaginado.

Cuando invocamos al Padre al inicio del PN, Él en persona se hace presente, se transparenta su semblante, llenándonos de sus dones e inundádonos con su amor. Pero en virtud de la gracia divina también se hacen presentes los hermanos en su dignidad y singularidad. El orante sabe muy bien que solo puede vivir ante la luz que desprende la presencia del Padre y de los hermanos. Quien reza esta plegaria percibe que no es un solitario sin hogar en este mundo, tiene la firme confianza de experimentar la compañía del Padre y vivir con el calor de los hermanos. ¿Qué consuelo real más hermoso que éste, vivido una y otra vez? ¿Quién podrá arrebatarnos la belleza de tener la seguridad de que el Padre nos acompaña en el camino y nos alienta con su Espíritu? ¿Qué experiencia más satisfactoria 
que sentir entre los hermanos la protección del Padre en la invitación que nos hace a la responsabilidad en beneficio de los semejantes?

El PN nos conduce no solo al Padre, también nos lleva a sentir la cercanía de los hermanos. En realidad, ese es el gran deseo del Padre común presente en la plegaria: congregar a los hombres dispersos en una fraternidad cordialmente unida que santifique su Nombre. Rezar el PN significa entonces adquirir fuerzas para vivir la hermandad y exultar de alegría, al conseguirla con la ayuda de la gracia. Cuando el orante se comunica con el Padre, la vida se vuelve más digna de ser acogida de forma filial y reconocida con actitud fraternal mediante el inmenso gozo de ser así con la fuerza proporcionada por el Espíritu.

La cercanía amorosa del Padre y de los hermanos lleva a la alabanza, concluye irremisiblemente en fiesta de adoración, admiración y acción de gracias. ¿Puede haber algo más bello tendente a la exultación que la unión familiar del Padre con los hijos considerados como hermanos entre los hermanos? ¿Puede existir un mejor futuro para la humanidad, donde en el presente no desaparecen las contiendas, sino que a menudo se incrementan, que comprobar la unión entre los hombres como hermanos queridos, que miran hacia adelante con confianza, porque nada tiene que temer de sus semejantes?

\subsection{En la casa común del Padre}

El PN, oración trinitaria de hijos y hermanos, como hemos mostrado una y otra vez, nos sitúa en la casa común de los hombres, que es la casa del Padre abierta de par en par a todos sin excepción. Casa en la que siempre ha encontrado cabida la totalidad de la humanidad, al menos en potencia: hombres y mujeres, niños y ancianos, jóvenes y adultos, solteros y casados, viudos y célibes, religiosos y laicos, blancos y negros, mestizos y amarillos, europeos y americanos, africanos, asiáticos y pobladores de Oceanía, aldeanos y urbanitas, pobres y ricos, sabios e ignorantes, buenos y malos, teístas y hasta ateos... el mundo entero sin excepción puede rezar el PN, porque nos pertenece a todos y toca de lleno nuestra condición humana, que a todos iguala sin diferencia alguna. Nadie puede negar a otro que rece la oración del Señor, porque a todos nos concede el Padre la gracia de poder dirigirnos a él con ilimitada libertad y confianza plena, sabiendo que siempre redunda en nuestro provecho. 
Y si nadie tiene el derecho de privar a otros de rezarlo, quiere decir que cualquiera puede participar en la praxis de su plegaria, para cambiar de comportamiento en la disposición interior orante de ser hijo y hermano. Nadie puede apropiárselo hasta el punto de negar a otros la posibilidad de rezarlo, aduciendo razonamientos que nunca podrán justificarse. Si el Padre hace salir el sol para buenos y malos y envía la lluvia tanto a justos como a injustos (Mt 5,45), ¿quién se atreverá a llevarle la contraria? ¿Qué belleza puede superar a esta declaración de principios, inherente implícitamente a la oración del Señor?

Cuanto más lo recemos, cuanto más entremos en su sentido y contenido, más iremos cayendo en la cuenta del bello trasfondo humano y espiritual, que impregna al PN, como núcleo esencial del Evangelio. Cuanto más lo convirtamos en plegaria común, orada y meditada, más nos sentiremos concernidos a actuar con y en el amor. Más creceremos como personas, en apertura a los otros. Y es que su invocación y sus peticiones nos van cincelando poco a poco como hombres nuevos y como trabajadores de la compasión, de la misericordia y de la paz.

\subsection{En el esplendor del Sermón de la Montaña}

No solo la exegesis moderna, también la filosofía y la investigación literaria han coincidido en sostener que el Sermón de la Montaña, universalmente reconocido por lo sublime de su mensaje, constituye una pieza sin parangón de la piedad religiosa y de la ética humana. Tiene que ver tanto con la fe como con el ethos, pero también con la excelencia literaria. Incluso estudios judíos lo han considerado como una auténtica pieza artística de belleza singular, mostrando su admiración ante él. Pocas palabras han llegado tan hondo al corazón de los humanos como las expresadas por Jesús en esta ocasión.

Los mejores comentarios a este discurso de Mt 5-7 coinciden en mantener la tesis de que el PN representa tanto su centro teológico como literario. Las enseñanzas de Jesús alcanzan su punto culminante, cuando habla de la esencia de la ley formada por la limosna, la oración y el ayuno (Mt 6,1-18) y al hablar de la oración nos enseña el PN, alzándose así como «el centro del centro», lo más granado de lo dicho y orado por Jesús, lo definitivo de la verdadera ley, lo que sostiene la fuerza del mandamiento nuevo del amor y lo que confiere consistencia el buen comportamiento con el propio cuerpo. 
Tres relaciones básicas construyen la vida y la actividad humanas: la relación con Dios, la relación con los otros hombres y la relación con uno mismo. Tienen un sentido circular y se complementan mutuamente. La relación orante con Dios, tal como la expresa el PN, se encuentra en el origen de las demás relaciones. Sólo quien mantiene una buena relación con el Padre de los cielos, sabrá que sus semejantes son verdaderos hermanos y que su dignidad pivota en el hecho de ser amado por el Padre y contado entre los hermanos. A esto nos lleva la auténtica oración, que funda la relación con la Trinidad Santa.

No puede tomarse por una exageración afirmar que la humanidad se juega su futuro en la asunción de este mensaje de amor, vida, verdad y también de belleza. Un mensaje que tiene que ver con la ayuda al prójimo necesitado. Sin una fraternidad efectiva entre las personas y los pueblos no será posible nunca la justicia y la paz en la forma deseada. La humanidad no habrá disipado los miedos de unos hombres contra otros y carecerá de un verdadero destino común. De ahí la importancia de la limosna, de las obras de misericordia en la relación con los otros.

Solo quien mantiene una buena relación con el Padre de los cielos, sabrá que su persona es su cuerpo, vivificado por el espíritu, que es participación del Espíritu del Padre y del Hijo. Y que ese cuerpo, que puede jugarle malas pasadas, está destinado a glorificar a Dios. Algo que únicamente podrá hacer, cuando oriente el ayuno (relación con uno mismo) en la forma que Pablo, el gran apóstol de la glorificación de Dios, aprendió de su Maestro Jesucristo:

«Os exhorto, pues, hermanos, por la misericordia de Dios, a que presentéis vuestros cuerpos como sacrificio vivo, santo, agradable a Dios; este es vuestro culto espiritual. Y no os amoldéis a este mundo, sino trasformaos por la renovación de la mente, para que sepáis discernir cuál es la voluntad de Dios, qué es lo bueno, lo que le agrada, lo perfecto» (Rm 12,1-2).

Estas palabras, de las más importantes existentes en el Segundo Testamento, merecen ser consignadas en letras de oro y, junto con el PN, ser recordadas siempre como oración claro está, pero también como verdaderas expresiones artísticas del mejor espíritu humano. El deseo paulino, expresado aquí, resume perfectamente la oración, la limosna y el ayuno, las tres realidades religiosas que unen a los cristianos con los judíos. 


\subsection{La vigencia atemporal del PN}

Lo más hermoso del PN consiste en que su atracción no acaba nunca, permanece siempre en nuestra memoria agradecida por su fuerza de convicción y verdad. Posee una vigencia perpetua, ya que no pasa su sentido en la vida cotidiana. Vale para todos los hombres, para todas las edades, para todos los tiempos y para todos los días, incluso para todas aquellas horas en que nuestro deseo del Padre se hace más apremiante y liberador.

Lo han rezado toda clase de gentes y en todas las situaciones vitales: santos y criminales, profesores de universidad y amas sencillas de casa, pobres de solemnidad y multimillonarios, grandes mandatarios y humildes ciudadanos, personajes de gran posición social, así como excluidos y marginados, encumbrados ante la opinión pública tanto como abandonados y descartados por ella. Nadie ha sido ajeno a su encanto y ayuda, a su consuelo y exigencia en el paso continuo e ininterrumpido de las generaciones. Y todo ello, porque posee la fuerza perenne de lo imperecedero y la fascinación que muy pocas obras de arte han logrado conseguir en la historia de la humanidad.

Aquí precisamente encuentra el PN su secreto más prometedor. Llega con tanta verdad, desprende tal cúmulo de fascinación, que cualquier persona, en la situación en que se encuentre en cualquier tiempo y lugar de la historia puede rezarlo y sentir la fuerza de su gracia. Se encuentra perfectamente retratado en sus peticiones, expresa sus deseos más íntimos en su búsqueda de la trascendencia, alcanza sus ansias de vida y amor, que anidan en el santuario de la conciencia. Y todo ello, porque penetra en lo más hondo de lo humano y llena como nada sus deseos. El PN tiene la grandeza de lo divino, ciertamente; pero también es humano, ¡y lo es hasta la médula! ¿Qué obra de arte como esta ha encontrado tanta resonancia, ha alcanzado a tantas personas y ha hecho tanto bien a los hombres en la historia del cristianismo?

En un tiempo de crisis e incertidumbre, incluso de drama global sobre el mundo, el PN representa una luz maravillosa en medio de las tinieblas de las sociedades actuales, asoladas por la pandemia del coronavirus. $\mathrm{La}$ fraternidad que patrocina, fundada en el Padre de los cielos, puede considerarse como un hecho ineludible para acercarnos a la reconciliación y trabajar por la paz, que necesitamos más que nunca y que siempre tiene que estar ahí, para no hundirnos en la crudeza del dolor, en la inhumani- 
dad de la violencia y en la hipocresía de la falsedad. La verdad, la bondad y la belleza, que desprende la oración del Señor constituyen un signo eficaz para sumar voluntades y unir almas en una convivencia necesaria hoy más que nunca, en la que la humanidad se sienta hermanada y defendida de las asechanzas del mal.

\subsection{En un nuevo nivel de la realidad}

La mejor manera de llegar a la verdad, la bondad y la belleza del PN es contemplándolo cuando se reza. Efectivamente, el PN alcanza su máxima expresión de comunicación, al ser contemplado en su contenido en acción. Conviene considerar que la contemplación constituye la máxima expresión de la vida intelectual y espiritual del ser humano en su búsqueda de lo que interesa de forma absoluta. Quien analiza el PN va más allá de la intuición estética, aunque también sea intuición estética. Se eleva por encima del arte, aunque sea también obra de arte. Supera la poesía, aunque sin duda tiene que ver mucho con ella. Sólo alcanza su objetivo último, cuando es vivido, no conceptualizado, contemplado, no simplemente reflexionado. Entonces, introducidos en la intimidad del Padre, estaremos en el camino para saborearlo como intuición estética, arte y poesía con sus múltiples implicaciones.

Para vivir el PN hemos de morir a nosotros mismos, dejar entrar en nuestra vida a Dios y permitirle hablar en el espacio más íntimo de nuestro interior, ya que es el auténtico protagonista de tan gloriosa plegaria. Orientado así, nos introducimos en una dimensión de la vida más honda y al mismo tiempo más elevada, únicamente posible desde la experiencia de la presencia del Padre, que actúa amorosamente en cada uno de nosotros inspirados por el Espíritu, que se abaja a todos. Entonces sentimos el gozo de estar junto a su persona, ser delante de su presencia, caminar con fidelidad mediante la asistencia de su gracia, que nunca nos abandona. Sólo cuando uno es «tocado» por la acción creadora y vivificadora divina, podemos comprobar que el PN tiene mucho de expresión estética, arte y poesía en grado sumo, pero que va más allá de ella, ya que se encuentra en un nuevo nivel de la realidad.

El PN contiene palabras salidas del corazón del Hijo humanado, que el Espíritu le inspiró y ahora nos inspira a nosotros, con las que podemos dialogar con el Padre, contestar a sus requerimientos afectuosos, dejando 
resonar en nuestro interior su misericordia, la fuerza de su cariño sin par. Dios habla en nosotros y percibirlo en nuestro interior significa tanto como sentir el gozo íntimo de ser hijos y hermanos a la vez. Lo más granado de la vida nos viene de esta oración bendita como amor del Padre en el Hijo por el Espíritu. Rezado y vivido así, el PN nos aleja de cualquier abstracción, para elevarnos a la dignidad suma de los hijos y hermanos del reino, que se sienten amados y, al mismo tiempo, vocacionados para el amor concreto y diario.

La intuición poética, el arte y la poesía acontecen en verdad, cuando se encarnan en la realidad en sí, que en el PN tiene que ver con la realidad misma de Dios y con la expresión de su amor, que va más allá de toda medida y únicamente se puede sentir, cuando es vida de verdad: consentida, contemplada y experimentada. En este sentido la intuición poética, el arte y la poesía tienen algo ¡o mucho! en común con la experiencia contemplativa, aunque no pueden reemplazarla, sí favorecerla. Esta permite a las personas mostrar lo que son y hasta dónde llega su capacidad de fruición, cuando logran alcanzar la belleza, la bondad y la verdad del Padre de los cielos. Ayudan a expresar lo inexpresable, a captar lo inabarcable, a gozar lo inalcanzable, lo que va más allá de toda dicha, impregnando el alma de un rastro indeleble. Importa que como orantes vivamos bajo la luz resplandenciente del Padre, dejarnos transfigurar por ese amor en la expresión de la plegaria, atrevernos a contemplar lo que excede las fuerzas humanas.

\section{BREVE COMENTARIO}

Entramos ahora en la explicación un tanto pormenorizada, aunque sea de manera sucinta. Seguimos la línea empleada desde el principio: llegar a descubrir la belleza de cuanto Jesús desea para el orante, sin que nos propongamos, algo que está ahora fuera de lugar: exponer aquí una exegesis amplia del PN, que puede verse en mi comentario mencionado al inicio. Basta con atenernos a algunas claves teológicas fundamentales, que se derivan de la correspondiente interpretación y nos ayudan a avanzar en el propósito deseado. 


\section{1. ¡Padre!}

La invocación sincera ;Padre! es toda una teofanía, significa penetrar en el ámbito más santo. En esa bendita invocación el mismo Padre se manifiesta y autodona a cada suplicante. Se trata de una de las expresiones más intensas de belleza, que podemos experimentar. No lo dudemos: En la invocación «Padre», «Abba», la divinidad del Padre se manifiesta de forma esplendorosa con toda la fuerza de su amor. Se está mostrando así la hermosura de Dios, que es Padre y Madre a la vez. Con la exclamación «Padre!» el orante se pone en comunicación familiar con Dios, se encuentra con Él en el calor del hogar, que se alarga por el mundo. No necesita más para entrar en la relación más directa, íntima y confiada que se puede pensar y desear. Para llegar al Creador del universo, al Omnipotente y Todopoderoso, no necesitamos movernos de donde estamos, cambiar de sitio y situarnos en otro ambiente; tampoco precisamos establecer un gran ceremonial, hasta el punto que después de recorrer estancias y superar no pocos obstáculos llegamos a la presencia de Alguien, harto difícil de acceder, por lo encumbrado que está en una soledad no compartida por su aislacionismo sublime. ¡No! Solo necesitamos invocarlo como El-queEs:;Padre!

No debemos escoger palabras grandilocuentes y exactas con las que podamos llegar a la meta deseada. Antes que lo invoquemos ya se encuentra junto a nosotros. Cuando conscientemente exclamos sin más ¡Padre!, Él está ahí junto a mí, junto a ti, junto a nosotros, para acogernos y derrochar con cada uno su amor. Y lo está, porque somos concientes de ello, aunque ahí se encuentra siempre, vuelto hacia nosotros. Para el orante ¿puede haber algo más consolador y bello que tener la seguridad de que la invocación realiza lo que dice la palabra, ya que lleva consigo siempre el inmenso consuelo de la presencia paterna? Por derecho propio entra en la intimidad de su familia. Esa familia nueva, que Jesús reúne en torno suyo y a la que pertenecen los discípulos, dispuestos a gritar jPadre! Y a tener en ese grito el santo y seña de toda su existencia y la puerta de la felicidad.

Porque poseemos la certeza de que pertenecemos a esa bendita familia no nos andamos con rodeos, cuando hablamos con el Padre; enseguida exponemos lo que queremos expresar, sin ceremonial alguno, adoptando falsas humildades y buscando caminos erráticos como puede 
ser el perderse en vana palabrería. Entramos en contacto vital con El que más queremos con la naturalidad propia del hijo, que habla con quien le conoce y está dispuesto a darle lo mejor que tiene, porque solo quiere el bien para el suplicante y para su vida (Mt 7,11).

El PN contiene así, en grado desacostumbrado, la característica más acusada de toda verdadera oración, tal como la practicó Jesús y nos enseñó a ponerla en práctica a cada uno de nosotros: dejar que el Padre entre en el orante, estando dispuesto a la correspondencia amorosa, al llenarse su persona también de calor entrañable. ¿Puede haber algo más hermoso? ¿No puede tanta belleza transformar por completo el interior humano, hacerlo más sensible al don de la gracia, más cristiano a las insinuaciones del Espíritu? La belleza del Padre se encuentra expresada en el corazón humano, basta que la acojamos con la sencillez, pero al mismo tiempo con la rotundidad, de quien sabe de que se ha encontrado con el gran tesoro de su vida y no está dispuesto a desperdiciarlo. Una perla preciosa que se esconde en su propio corazón y basta con encontrarla.

En la invocación «Padre» se expresa la vuelta del hombre a Dios; y lo hace de la mano de Jesucristo. El hombre se había separado de Dios, primero en Adán y Eva, después en los otros humanos desde los inicios de la humanidad. Con nuestros pecados nos separamos de nuestro Creador y Señor. Jesús, el Hombre por excelencia, nos enseña a retornar a la casa paterna, llamados por nuestro nombre e invitados a vivir como personas renovadas. Al invocarlo con entera confianza ;Padre!, no solo activamos la conversión, también experimentamos su presencia bondadosa, que está ahí para nosotros, aunque en no pocas ocasiones no lo percibamos. Mediante el cambio de mentalidad y actuación percibimos la suave gracia de la salvación, que el Padre nos ofrece en el Hijo a los que somos convocados para ser sus hijos. ¡Qué belleza tan grande pronunciar esta invocación! En ella prevalece el sentimiento, la afectuosidad, sobre todo lo demás, porque nos sentimos irradiados por el amor divino, lleno de ternura y entrañabilidad, con la respuesta siempre pobre pero ineludible de nuestro propio amor.

Sentir y experimentar la bondad del Padre constituye una revolución de la que no nos damos cuenta en todo lo que significa. Está ahí actuante como algo maravilloso, dando sentido a la existencia humana. Supone sentirse acogidos, acompañados y queridos, con todo lo que estos sentimien- 
tos valen. Tiene además como consecuencia la sorpresa, de que merece la pena vivir sostenidos por el Padre bueno que incluso nos lleva en sus brazos y nos llena de caricias. Nadie nos puede privar de la alegría que supone el cariño, la relajante afectividad, que el Padre nos proporciona. ¿Hay algo más hermoso? ¡La reacción no puede ser otra que la positividad y la afirmación de la vida en lo que tiene de más preciado!

Esto no quiere decir que todo lo contemplemos de color de rosa, separados de los problemas reales que la cotidianeidad nos depara. No. Toda la carga de la realidad sigue en su sitio. La realidad es la que hay y no nos queda más remedio que aceptarla. Aún más, resulta necesario verla, entenderla, no desviarla o camuflarla. Precisamos dejarnos interpelar por ella y afrontarla con la mayor de las decisiones. Pero los problemas, grandes y pequeños, se afrontan de una manera bien distinta, cuando nos consideramos sostenidos por el amor del Padre bueno, que nos llama a la fraternidad. Hay cosas de las que podemos arrepentirnos en nuestra andadura, por el daño que nos han hecho a nosotros o a nuestro prójimo. De sabernos acogidos y amados por el Padre y de responder con responsabilidad y fidelidad a ese amor, nunca nos arrepentiremos, porque se autentifica como una excelente elección, que nos recrea como personas nuevas. Siempre estaremos orgullosos de haber encontrado el tesoro de nuestra vida y haberlo guardado como el regalo más preciado recibido.

En resumen: El PN nos transmite algo muy hermoso: ¡No somos huérfanos, no nos encontramos perdidos en medio del mundo hostil, tenemos un Padre-Madre y una familia, que nos protege, en la que creemos por encima de todo y nos sentimos arropados por su calor! No podemos vivir sin trascendencia, sin levantar los ojos hacia lo alto y considerar lo que somos, dejando a un lado al Padre de los cielos, porque en el amparo divino se encuentra la razón de nuestra existencia, las ansias de proseguir el camino, el sentido de los que somos y hacemos. ¡Qué negrura y feura vegetar como orugas al margen del Padre y qué luminosidad y hermosura dejarnos acompañar por el Padre bueno de rostro luminoso, que a todos nos acoge y hermana!

\subsection{Las siete peticiones}

Ya hemos indicado que las tres primeras peticiones del PN en Mateo (dos en Lucas) se las suele llamar «peticiones tú». Contienen tres realida- 
des centrales de la causa del Padre, contemplado como el Tú por excelencia: «tu Nombre», «tu Reino», «tu Voluntad». Las cuatro restantes (tres en Lucas) se las denomina «peticiones nosotros», ya que presentan la causa del hombre: «nuestro pan», «nuestras ofensas», «nuestras tentaciones», «nuestros males». Con fina precisión Fray Luis de León señala que el PN, en el que vive el mismo Espíritu de Cristo, llega a las dos partes del alma: «en la primera, que es la celestial, santificándola, o si lo habemos de decir así, haciéndola como Dios; y en la segunda, que mira a la carne, apurándola y mortificándola de lo carnal y vicioso».

\subsubsection{Las peticiones «tú»}

Esta tríada de peticiones ofrece una gran unidad y puede ser tratada conjuntamente. Mientras las cuatro peticiones «nosotros» abordan las preocupaciones humanas de cada día, la tríada que ahora comentamos habla de las preocupaciones del Padre: su Nombre, su Reino, su Voluntad; preocupaciones que tiene a bien poner en juego para beneficio de los humanos, compartiéndolas con nosotros. Nada tienen que ver con el egoísmo sino con el amor. El Padre santifica su Nombre, cuando los hombres nos dejamos congregar en una gran fraternidad, que Jesús va reuniendo con sus discípulos en su nombre. El Padre activa el Reino y le concede el incremento, cuando los humanos acogemos con gozo y libertad, con consciencia y responsabilidad el corazón de hijos y hermanos que el Padre bueno desea regalarnos. El Padre se ocupa y preocupa del mundo y tiene trazado un plan de salvación sobre él, que Jesús desea implantar en la sociedad de su tiempo.

Por eso, lo mejor que puede pasar en la tierra es que la voluntad divina, del mismo modo que se realiza plenamente en el cielo y los bienaventurados viven dichosos a su amparo, también en la tierra se cumplan los designios salvíficos divinos. En definitiva: con la actuación del Padre se origina algo realmente nuevo. Se da un giro radical a la historia, porque surgen, al hilo de la oración, nuevas relaciones con Dios, con los hombres y con uno mismo, como ya hemos desarrollado desde otra perspectiva anteriormente. El gran acontecimiento empieza en uno mismo y en su relación con la fraternidad. Esta es precisamente la transformadora y hermosa, tiene que ver con la alegre y buena noticia que encierra el PN en sus primeras peticiones, que desprenden una singular belleza. 
La belleza no consiste tan sólo en contemplar la creación y la creatura humana en su esplendor. Belleza significa también obrar rectamente, conforme al plan del Padre, de modo que el universo entero, y dentro de él el hombre, correspondan cada vez más a la voluntad divina, tal como Cristo la ha obedecido, y a su vez, se realiza también en la Iglesia, Cuerpo de Cristo y discípula de su Maestro. El arte, la belleza ayudan a transformar la realidad. Cuanto más aparece el esplendor de la belleza más fácil resulta contemplar el plan de Dios en la historia.

Cambiar para bien las relaciones interpersonales conforme a los designios divinos transforma la realidad y, a su vez, transparenta una gran belleza. En última instancia la belleza tiene que ver siempre con el ennoblecimiento de la realidad. Y nada la ennoblece más que la cooperación humana a la realización de las tres peticiones «tu» del PN en la historia. En su puesta en práctica se descubre el esplendor original del Padre, que todo lo hizo y hace bien y está dispuesto a dar su gracia a quienes obran a su imagen, siendo testigos activos del amor divino en el mundo. La belleza contempla la realidad tal como es; la ensalza a su vez y testimonia su verdad, que sólo resulta posible mediante la acción.

En resumen: Las tres primeras peticiones ofrecen un denominador común de importancia decisiva para el presente y futuro tanto de cada hombre como de los hombres en su totalidad. Conducen al orante a vivir desde la Trinidad Santa, a ponerse en sus manos, las más bellas que existen. Las tres peticiones nos llevan a reconocer el Santo Nombre del Dios Trino, a acoger su Bendito Reino y a cumplir la Voluntad Divina, como camino seguro para ser feliz, hacer un mundo más humano y procurar para la humanidad un hogar habitable y hermoso. Y es que el Padre bueno, a quien nos dirigimos no busca otra cosa que la plena realización de las personas concretas y la felicidad de cada una de ellas. Lo creamos o no, la alegría de vivir podemos encontrarla en nuestra interioridad, en la experiencia de la benevolencia del Padre.

\subsubsection{Las peticiones «nosotros»}

Asistimos a un cambio bien significativo en las peticiones. Las cosas pedidas ahora, por un lado, tienen que ver con lo concreto y lo cotidiano, pero por otro lado poseen gran importancia, por empalmar con lo central de la propia experiencia, que no deja de manifestarse a lo largo de la vida. 
Por eso descubren los aspectos fundamentales de la condición humana en su relación con la trascendencia: la corporeidad, la presencia del pecado, así como el peso tanto de la ofensa como de la culpa, la inevitabilidad de la tentación y el problema irresuelto del mal. ¿No conforman estas realidades las dimensiones más enraizadas en el ser y obrar humanos? Las cuatro, sobre todo la tercera, constituyen un grito de socorro ante la dureza de la vida y ante el peligro inminente de torcer las convicciones más profundas. El grito de quien quiere vivir como persona y se encuentra amenazado de continuo por la necesidad física, por la culpa, la tentación y el mal.

El Padre puede ayudar decisivamente, pero siempre sin postergar y menos despreciar la propia actuación responsable. Estamos ante el grito de la belleza, que invita a no disolverse en la nada y buscar una y otra vez el ser propio, al que el Padre llama. Fascina comprobar cómo estas peticiones presentan a Dios en el mundo, en el corazón mismo de las ocupaciones y preocupaciones humanas. El Padre está a nuestro lado, camina en la cercanía y nos proporciona el Espíritu, con el que somos capaces de salir airosos de las emboscadas que las distintas formas del mal nos pueden tender. ¿Acaso hay una mayor esperanza que ésta, tan hermosamente expresada por san Pablo: «Si Dios está con nosotros...»(Rom 8,31ss)... quién conseguirá derrotarnos?

a) El hombre es su cuerpo. Lo mismo que es su espíritu. Ambas perspectivas forman una unidad inseparable en la vida terrena. Pues bien, el cuerpo necesita insoslayablemente el sustento diario para poder llevar una existencia digna. Por eso el orante pide al Padre con confianza que no le falte el alimento diario, aunque sin intentar acaparar bienes materiales que puedan ir en detrimento de la fraternidad. Por eso la petición va más allá e incluye el pan de la fraternidad y el de la eucaristía como algo imprescindible para vivir como creyentes y hermanos. Estamos ante el cuerpo abierto a las necesidades el espíritu.

b) El perdón de los pecados resulta factible allí donde se reconoce la soberanía de Dios, capaz de restablecer nuevas relaciones entre los hombres, donde parecía imposible mantenerlas. Si algo necesitamos los humanos es sentir la experiencia del perdón divino, ya que somos pecadores. Pero ese perdón hace de nosotros testigos del perdón divino con capacidad para perdonar a los que nos ofenden. Reconocida la compasion y mi- 
sericordia divina en la propia vida, nada nos hace más humanos y cristianos que abrirnos al perdón sin límites como lo hizo Jesucristo y lo manifestó de manera estremecedora en la Cruz.

c) Lo peor que le puede pasar al discípulo y al hombre en general consiste en pervertir la vocación y alejarse de la misión a las que ha sido llamado. Nadie escapa a esta tentación por bueno que sea y centrado que esté en su religiosidad. De ahí la necesidad de la fe para gritar ayuda ante el Padre, cuando sea necesario recurrir a su auxilio. Cuanto mayor es la prueba, más purificada se vuelve la fe, cuando sale victoriosa con la ayuda inestimable de la gracia. De ahí que podamos gritar: «Padre bueno asístenos en la tentación, de un modo muy especial, cuando sea grande y escape a nuestras fuerzas». «Que podamos superar la prueba, porque nunca nos falta la ayuda tu Espíritu con la que siempre contamos». ¿No tiene una gran belleza este grito de socorro ante Dios, así como reconocer la propia impotencia, siempre con la firme voluntad de querer salir de la debilidad?

d) Muy posiblemente la oración de Jesús concluía con la alusión a la tentación, aunque Mateo la ha completado, sacando a relucir el tema del mal, tan vinculado con las pruebas por las que pasamos. Quien más nos tienta es el maligno, de ahí que la petición pueda formularse también así: líbranos del Malo, que no es otro que Satanás, el padre de la mentira, el destructor del amor y el mayor enemigo de los seres humanos. El mal concreta la tentación y busca destruir la bondad, la verdad y la belleza, que existe en cada persona. El mal, como el nombre indica, nos hace mal a nosotros y a los demás en lo más íntimo. De ahí que tengamos que evitarlo con la ayuda de la gracia y con la puesta en práctica de nuestras propias fuerzas.

Si propio de toda obra de arte es el realismo, pero no un realismo chato que termina en la catástrofe, sino un realismo abierto a la esperanza, las cuatro peticiones formuladas en este apartado constituyen una obra de arte. El hombre es lo que está llamado a ser, tal como se deja traslucir en esas peticiones. Y nada hay que corresponda mejor al ser humano que ir más allá en sus realizaciones concretas, ya que tiene multitud de posibilidades aun no adquiridas. Esto es precisamente lo que aparece desde las perspectivas esenciales de cada persona en las cuatro peticiones comentadas aquí.

Una constatación final, muy unida a lo que acabamos de exponer: con bastante probabilidad tanto la última de las peticiones «tu», como la 
última de las peticiones «nosotros» de Mateo, no aparecían en la oración rezada por Jesús la primera vez. Pero Mateo integró aquí ambas peticiones, que Jesús había formulado en otras ocasiones, ya que encajaban perfectamente en el original, dejando así constancia que el PN constituye una oración abierta, con un gran poder evocador, algo que tiene que ver también con la trascendencia inherente a toda forma de verdadera belleza. ¿Quién podrá entrar en el interior de todos los que hemos rezado y los que rezarán el PN? ¡Qué enriquecedora relación con el Padre descubriríamos! Me atrevo a describirlo y actualizarlo para el hombre de hoy de esta manera:

Padre del cielo, somos tus hijos, tu amada familia, la comunidad que deseas reunir en torno a tu mesa para hacer de ella una fraternidad sin fin. Por eso con la ayuda de tu Espíritu podemos llamarte nuestro Padre de verdad: ¡Abba querido!

Revélate a todas las naciones como el Dios santo que eres. Reúne a tu pueblo que con frecuencia se encuentra disperso, dividido y hasta peleado entre sí. Haz de él tu verdadera familia, congregada por tus desvelos con nosotros, de modo que tu Nombre reciba el honor que merece ante todo el mundo. Regálanos la fuerza de tu Espíritu, para constituirnos como comunidad en tu Nombre, dispuestos a caminar juntos como una piña. Santificado sea tu nombre.

Irrumpe con tu amorosa soberanía en el universo. Sé tú nuestro único Señor liberador. No queremos servir por más tiempo a dioses e ídolos, que nos esclavizan y nos impiden vivir como hijos y hermanos. Danos tu Espíritu, para testimoniarte como tu familia de manera verdaderamente humana, sin recurrir a la violencia y echarnos a perder con el odio y las luchas fraticidas. Siempre dispuestos a favorecer la concordia y a trabajar por la paz, buscando la solidaridad con los más pobres y la compasión con los heridos. Venga a nosotros tu Reino.

Lleva a plenitud tus designios de salvación, esos designios que tienes para la humanidad entera y que tomaste desde toda la eternidad. Lo que se cumple siempre en el cielo, que se haga realidad también en la tierra, porque estamos convencidos de tu bondad, de la que ya están disfrutando los bienaventurados. Lo que late en tu corazón, lata del mismo modo en el nuestro, ávido de tu complacencia y generosidad. Concédenos tu Espíritu para ser testigos de tu proyecto de amor y así poder colaborar gozo- 
samente en él sin ataduras de ninguna clase. Hágase tu voluntad en la tierra como en el cielo.

Danos el pan que en este momento necesitamos para pasar de manera digna la jornada. No permitas que amontonemos lo que otros precisan para poder subsistir, siendo generosos en el compartir y prestos en el ayudar. Envíanos tu Espíritu para que ansiemos también el pan de la fraternidad y de la Eucaristía, de modo que ellas sean más importantes para cada uno de nosotros que el sustento diario, al que no podemos renunciar. Danos hoy nuestro pan de cada día.

Perdódanos las deudas que tenemos contraídas contigo y que nunca podremos resarcir. Líbranos de la injusticia con los demás, abiertos a la experiencia de tu perdón. Haz de nosotros personas dispuestas a perdonar a los que nos hacen mal, por grande que sea. Infúndenos tu Espíritu para que comprendamos vitalmente que no podemos esperar tu perdón, si no estamos dispuestos igualmente a usarlo también nosotros con los hermanos. Perdona nuestras ofensas, como también nosotros perdonamos a los que nos ofenden.

La tentación nos amenaza por doquier constantemente y se afana en impedir que seamos mejores, imitemos tu amor, haya un mundo mejor y una tierra renovada con nuestra colaboración. Entréganos tu Espíritu para que la tentación, fruto del mal, no nos lleve a una situación tal en la que nos apartemos de tu bondad y del servicio al necesitado. No nos dejes caer en la tentación.

Porque el mal se opone con todas sus fuerzas y artimañas a que venga tu Reino, porque su fuerza antidivina destruye lo que tú tratas de construir con nuestra ayuda, concédenos la fuerza necesaria para resistirlo. Danos tu Espíritu, lo más opuesto al Malo, que es el antiespíritu, para que nos haga caer en la cuenta que no podemos servir a dos señores, a Ti, que eres el Bien Ansoluto y al Malo, que es lo peor de tiene el mundo. Y líbranos del mal.

\subsubsection{En resumen}

La invocación y las peticiones del PN despiden un maravilloso sentido poético, cargado de belleza, ritmo y sonoridad espiritual. Que esta oración haya sido aprendida de memoria por tantas generaciones creyentes y rezado con frecuencia cotidiana por tantas y tantas comunidades cristianas, 
desde que Jesús la pronunció en un día glorioso, tiene mucho que ver con su precioso contenido, que despide la verdad de la poesía y la fascinación por la obra de arte.

Como ningún otro texto, el PN nos lleva a la conversión, al cambio de vida personal y comunitario; en última instancia al encuentro amoroso con el Padre y al servicio incondicional de los hermanos desde el gozarse en el amor, la responsabilidad, el compartir y el perdón. Además, la oración del Señor nos confronta con nuestra misión de glorificar a Dios por encima de todas las cosas, pero en las cosas; de acoger su Reino mediante el anuncio gozoso del Evangelio, que el Padre encargó al Hijo y que el Hijo nos encarga hoy a nosotros, teniendo siempre sus mismos sentimientos y obrando con el propio estilo de vida que Él tuvo.

No lo olvidemos nunca: esta plegaria bendita aviva como nada nuestra pobre fe, fortalece nuestro amor, siempre escaso, y nos llena de la luminosidad de la esperanza, para vivir con sentido la vida de cada día, aguardando la futura consumación final. El PN es personal y se vive en comunidad. Da mayores frutos cuando es rezado delante de la presencia de Cristo y en compañía de los hermanos, que nos ayudan a sentiros verdaderos hijos del Padre en el Hijo.

\section{EL PN SIEMPRE EN EL CENTRO}

Jesucristo, el Mesías de Israel y el Hijo de Dios, se alza en la historia como la figura básica, el motivo primero, así como la referencia central del cristianismo de todos los tiempos: del presente, del pasado y del futuro. El Jesús terreno puede ser considerado como un poeta de primer rango, que con sus oraciones (Q 10,21-22;11,2-4; Mc 14,36 par.) y parábolas transformó el concepto de Dios, la idea del hombre y hasta la configuración del mundo como nadie antes lo había hecho hasta entonces. Y pienso que como nadie lo hará después de él. Lo hizo con la sencillez y eficacia de los auténticos místicos, formando a su alrededor un movimiento de seguidores continuadores de su obra. Sus enseñanzas, además de verdaderas, alcanzan lo sublime en grado superlativo. 


\subsection{Significación del PN}

Entre todo su legado la plegaria del PN adquiere una significación muy especial, incluso desde el punto de vista artístico, como hemos mostrado pormenorizadamente en este estudio. Constituye todo un canto bellísimo a la verdad y a la grandeza, que anidan en el corazón de las personas, cuando se dejan transformar por la buena noticia del Evangelio, siguiendo las insinuaciones del Espíritu. Y lo más sorprendente consiste en que lo hace con una brevedad nunca alcanzada, sabiendo seleccionar las palabras y escogiendo los motivos centrales de una acendrada espiritualidad. Además, acierta con una singular precisión, para llegar allí donde se encuentra el verdadero secreto de la existencia humana. Lo formula alguien que sabe muy bien quién es Dios y expresa su convicción más profunda con soberano acierto, porque tiene experiencia directa e inmediata de que Dios es ante todo y sobre todo Padre.

El PN únicamente se puede entender en profundidad desde la perspectiva trinitaria. El encuentro orante con el Padre se realiza a través del Hijo Jesucristo con la fuerza del Espíritu, que nos convierte en hijos de Dios con la posibilidad de clamar ante su presencia ;Abba! (Rom 8,15; Gal 4,6). El creyente encuentra en la Trinidad el sentido de su existencia, así como la meta primera y última tanto de su vida como de su oración. La Trinidad, que representa el núcleo central del cristianismo, constituye también el meollo mismo de esta bendita oración, cuando se analiza en toda su hondura. El Padre es mencionado directamente, el Hijo humanado es quien formula la oración y el Espíritu en su invisibilidad alienta la experiencia filial y la sinceridad de las peticiones por parte de los constituidos en verdaderos hermanos.

El creyente entra a participar de los dones cristianos mediante la invocación de la Trinidad en el bautismo. Del mismo modo logra experimentar los gozos de la oración y, como no podía ser por menos, también del PN, mediante la experiencia de la Trinidad. Si pertenece a la identidad más propia del arte mostrar la realidad esplendorosa de la belleza, no existe verdad más bella y gozosa que el amor infinito del Padre para el hombre, así como la salvación del Hijo humanado mediante la acción santificadora del Espíritu; y eso es precisamente lo que encierra en sí misma la oración del PN, cuando se la considera en toda su hondura.

La belleza tiene que ver con descubrimientos, que ayudan a la felicidad humana en el presente y en el futuro. Mostrándonos al Padre se revela 
como lo que es, como el Hijo Unigénito, unido a su Bendito Progenitor por los lazos indestructibles de la caridad del Espíritu, esencia misma del obrar divino. A la vez nos descubre, he aquí la buena nueva para todos los tiempos, que pertenece a la misma raíz de la esencia humana el ser-hijospara-vivir-como-hermanos. ¡Puede haber algo más hermoso en el descubrimiento de la verdad inherente a la propia identidad! Y así podemos aparecer ante el Padre como lo que somos: hijos de verdad en el Hijo, que en su día heredarán la bienaventuranza eterna. La solicitud y preocupación de Dios Trino por la humanidad, tiene que ser también la preocupación del discípulo del Hijo del Padre en su cuidado por sus semejantes en la casa común de la creación. ¡Cuánta belleza!

Siguiendo estas pautas, nos alienta a experimentar que, en el Hermano Mayor que no es otro que el Hijo humanado del Padre, todos los hombres estamos llamados a relacionarnos como auténticos hermanos, ya que formamos parte de una misma familia, presidida por un Padre común, que quiere lo mejor para cada uno de nosotros. Estaremos cerca o lejos de la filiación y de la fraternidad, en la medida que nos situemos en el origen y fundamento del PN y descubramos, mediante la experiencia gozosa, vivida, testimoniada, agradecida, alabada y proclamada, su verdad y su belleza transformadoras del interior humano. Conviene proclamar sin miedo, con valentía el deseo que impregna el PN: La humanidad tendrá un destino asegurado, cuando se vaya haciendo presente y actuante la fraternidad entre los pueblos, fuente de derecho y referencia insustituible de verdad y belleza para todas las generaciones.

En pocas palabras, en la teología cristiana existe algo especialmente bello a lo que hay que volver una y otra vez, como origen primero e insustituible de la novedad, que descubren las raíces mismas de nuestra fe:

- el amor entrañable, lleno de misericordia, del Padre bueno siempre vuelto hacia los hombres, porque nos lo ha dado todo;

- la salvación concreta del Hijo hecho hombre para regenerar a la humanidad caída y devolverle la grandeza que había perdido con el pecado;

- la santificación creadora del Espíritu Santo, enviado por el Padre y el Hijo en orden a transformar a los humanos en personas nuevas, llamadas a desarrollar la dignidad de los hijos y hermanos del Reino. 


\subsection{Volver a la realidad primera}

Una y otra vez el PN nos devuelve a la realidad primera, que llena al orante de asombro y belleza y que no puedemos olvidar nunca dada su trascendencia. Rezar una y otra vez el PN nos centra en lo esencial, en la raíz misma de la que deriva el ser humano. Orar con la oración del Señor no nos permite olvidar el bien, que anida en nuestro interior y que nos aparta de volver a la barbarie, que acecha al hombre de mil maneras. Nos lleva insoslayablemente a la práctica del amor, en el que la persona alcanza su mayor realización.

¿Hay algo más hermoso que volver una y otra vez a la realidad primera de la Trinidad, como fuente de vida y amor? Y esto es precisamente lo que el PN hace cada vez que lo rezamos en nombre de Jesús. Así aparece señalado magistralmente, de forma explícita unas veces e implícita otras, en esta admirable oración con la simplicidad y destreza de la obra maestra, consumada por el excelente artista llamado Jesús de Nazaret. Vivió lo que anunció y anunció lo que vivió con hermosas, consoladoras y liberadoras palabras de amor y verdad. Su belleza interior queda reflejada en su oración y de forma singular en el Padrenuesto.

Las preocupaciones de este mundo vienen y van. Caen las urgencias de cada día, como las hojas de los árboles. Pero hay Alguien que siempre está con nosotros y nos acompaña aquí y ahora. Es el Padre Santo, que no nos deja solos, nunca se ha ido de nuestro entorno, que nos llama a la comunidad de vida compartida. A ese Ser bendito de los cielos le tenemos junto a nosotros, siempre que le invocamos: ¡Padre! ¿Hay algo más hermoso que la fe cierta de encontrarnos continuamente con el Padre bueno, que nos llena de la salvación del Hijo y del amor del Espíritu?

A algunos hablar al Padre de tú a tú les puede parecer subido de tono y hasta descarado, no a Jesús y a sus seguidores, que conocen la amabilidad divina. El PN ayuda al orante a experimentar la presencia transparente del Padre en el Hijo y a reconstruir con la gracia del Espíritu la propia existencia, insertándola en la comunidad de los hijos y hermanos del Reino. El trato entrañable y familiar con el Padre lejos de ser impertinente resulta la manera original cristiana de relacionarse con El Que nos interesa más que nada y nadie y se encuentra en el origen de la salvación y en la culminación de la felicidad humana. 


\title{
6.3. Las cosas especialmente hermosas
}

Pocas cosas tan hermosas, como haber sido alcanzados y sostenidos por la oración del Señor, que nos invita en todo momento a intimar con el Padre de los cielos, a abrirle nuestro corazón. Nada más bello que conocerlo y amarlo de modo semejante a como Él nos conoce y ama. El amor divino nos convierte en familia de hijos y hermanos, nos transforma en una inmensa fraternidad, abierta a la verdad y el amor. ¡Cuántas veces lo hemos dicho, porque nos viene bien repetirlo y sobre todo creérnoslo! En la maravilla del PN Jesús nos invita a seguir el orden bello, inspirado por el Espíritu, que arranca del Padre y se asienta en el hermano, empezando por los más pequeños. Se trata del orden erradicado en la verdad y el amor divinos, que se plasman en el corazón del hombre como buena noticia de salvación, digna de ser puesta en práctica y de llenar de sentido la propia vida. Esta oración obra en el deseo de permanecer en el bien, que rige lo más hondo de la existencia humana.

¿Podemos aspirar a experimentar belleza mayor? Que el Espíritu haga palpable la fuerza de la bondad de nuestro $A b b a$, que haga visible también ante nuestros ojos el esplendor de tanta belleza. En fin, el PN nos transmite algo sublime, que no puede ser más consolador y hermoso, a la vez. Rezo, luego existo felizmente con todas las consecuencias. Pero existo no colgado de la nada, sino sostenido en los brazos amorosos del Padre, que en el Espíritu me regala, nos regala su amor con el mismo infinito amor con que ama al propio Hijo. ¡Cuánto gozo en esta belleza!

\author{
SEgUNDA PARTE: \\ LA BELLEZA DE LAS IMÁGENES DEL PN \\ EN LOS SALTERIOS
}

\section{INTRODUCCIÓN: SALTERIOS Y EVANGELIARIOS}

Toda la Biblia, en realidad es una biblioteca de setenta y tres libros. Cuando la abres, transparenta espiritualidad, despide belleza por cualquiera 
de sus páginas. Le cabe la gloria de ser la obra más leída y representada en imágenes de la historia de la humanidad. Entre todas sus aportaciones más espléndidas destacan de una manera especial en el Primer Testamento, el Libro de los Salmos y, en el Segundo Testamento, los Evangelios. Dada su especial belleza, los artistas han prestado a ambos escritos una esmerada atención, poniendo imágenes preciosas en sus creaciones. Los creyentes no podemos vivir sin ellos; de ahí que hayan sido tan leídos, comentados, rezados y puestos en imágenes, que se entrecruzan entre sí. Contamos con un gran número de salterios y evangeliarios que contienen primorosas miniaturas, que nos muestran de manera magnífica la singular belleza, que se esconde detrás de los poemas y relatos inherentes a la tradición judeo-cristiana.

De una manera muy especial, a raíz del Concilio Vaticano II, más en el momento actual que en los siglos de la Edad Media, los Evangelios y los Salterios alimentan la espiritualidad de los clérigos, religiosos y laicos, sirviendo por igual para la liturgia solemne, así como para actos de piedad tanto personal como comunitaria. Por encima de los demás textos destaca la oración del $P N$, la más popular de todos los textos bíblicos, aprendida de memoria con facilidad y recitada por todas las generaciones cristianas.

De acuerdo con lo que acabamos de expresar, cada uno de los salmos no puede considerarse tan solo como un número conforme se cita para distinguir su contenido. Tampoco contiene una espiritualidad hueca, que está pasada de moda desde hace mucho tiempo y hoy se nos cae de las manos; bien al contrario, ofrece una religiosidad viva, en la que el salmista se desnuda delante de la presencia divina y con una sinceridad admirable, presenta su vida ante la presencia de quien puede entenderle y ayudarle en su existencia cotidiana, en la que no faltan pequeñas y grandes dificultades necesitadas de ser conocidas, superadas y sublimadas por el Todopoderoso. Tanto los salmos como los evangelios ofrecen una perenne actualidad: se recurre a ellos en el presente, tendrán vigencia en el futuro, aunque vengan de un pasado de miles de años.

Muchos de los mejores códices de los salmos contienen un ciclo completo de escenas tomadas de la vida de Jesús, ya que interpretan los salmos cristológicamente en dos sentidos complementarios: es el mismo Cristo quien habla en ellos y, en no pocas ocasiones, van dirigidos a su persona divina como Hijo del Padre. De esta manera los salmos y los evangelios tienen mucho de común en los códices, como vamos a mostrar en esta segunda parte. 


\section{EI Libro de los Salmos}

Ningún libro del Primer Testamento ofrece aspectos tan humanos y sinceros como el Libro de los Salmos. Estos pueden considerarse como testimonios de una religiosidad no falseada, que llega a lo más profundo de lo que reporta la existencia cotidiana vivida con intensidad religiosa. Sorprende a nuestra piedad con toda clase de descripciones de pensamientos, sentimientos y comportamientos, inherentes a la condición humana. Sus páginas pasan de la alegría al llanto, de la risa a la lágrima, de la exaltación a la imprecación, de la acción de gracias a la queja existencial, de la alabanza incondicional a la petición interesada, de la aceptación del prójimo a la maldición de los enemigos, de la constatación de lo bueno al rechazo de lo malo, porque así se comporta el hombre religioso en sus estados de ánimo a lo largo de su andadura histórica.

Los contrastes aparecen con frecuencia, para mostrar toda la hondura existencial de la que la persona es capaz, trazando el modo concreto como el alma se eleva a Dios entre los muchos avatares de este mundo. Todo lo humano vale para dirigirse a Dios y suplicarle ante las muchas necesidades que acucian al hombre en su discurrir diario. No nos tiene que extrañar entonces que los salterios con imágenes, que recogen todo este mundo interior, lleno de alegrías, pero también de conflictos, se encuentren entre los códices más bellos e impresionantes de la Edad Media.

\section{EI Salmo 22}

Imbuido de la piedad bíblica, posiblemente Jesús conocía todo el salterio de memoria, como muchos de los piadosos judíos de la época. Algunos afirman que rezó todo el Salmo 22 en la Cruz. Es altamente significativo que el grito de sus palabras iniciales está testimoniado por la llamada Pasión premarquina, probablemente el primer documento del Segundo Testamento. Cita esas palabras incluso en su idioma original para conferirle más realismo ${ }^{2}$. Jesús, humano entre los humanos, pasó en sus plegarias por algunos de los estadios explicados anteriormente; sobre todo del gozo al sufrimiento, como aparece en la celebración de la última cena y durante los momentos sublimes de su agonía en Getsemaní.

${ }^{2}$ Cf Luis Ángel Montes Peral, Dios mío, Dios mío ¿porqué me has abandonado? San Pablo, Madrid 2017. 
Pero invariablemente Jesús siempre acaba con el mismo deseo: Padre, que se haga tu voluntad, no lo que yo quiero. Acepta el sufrimiento, se somete a su desgarro, como parte integrante de su redención incondicional en beneficio de los hombres y como expresión de su amor pro-existente, ex-propiado y ex-céntrico.

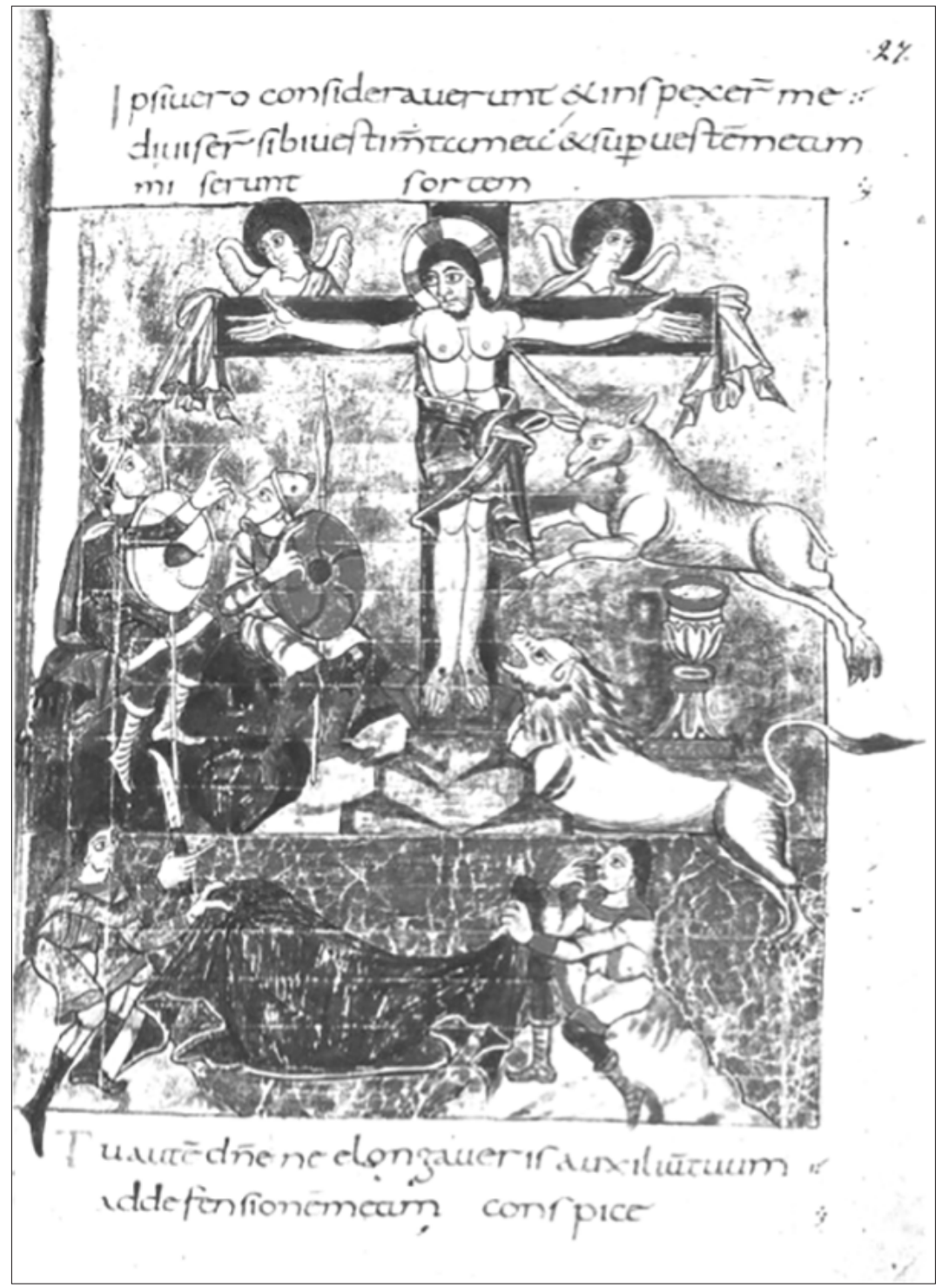




\section{El Salmo 22 en el Salterio en imágenes de Stuttgart}

El salterio más antiguo completo, conservado en la actualidad, es el llamado Stuttgarter Bilderpsalter, es decir, el Salterio en imágenes de Stuttgart, que se conserva en la Württembergische Landesbibliothek de la mencionada ciudad alemana con la signatura (Bibl. Fol. 23). Espléndido ejemplar, el más importante de esta biblioteca, que fue compuesto entre los años 770 al 790 y contiene la más numerosa serie de pinturas sobre los salmos de toda la Edad Media: Nada menos que 470 escenas bíblicas individuales, correspondientes a 316 miniaturas, en 168 hojas de pergamino de 26,5 por $17,5 \mathrm{~cm}$. Lo que hacen de este ejemplar un códice de una importancia excepcional por su antigüedad y belleza. Las miniaturas, de varias manos ofrecidas en él, tienen la clara función de preparar para el texto y ayudar a entenderlo, de modo que existe una fecunda interrelación entre la imagen y el contenido de cada salmo. En los márgenes de las 18 primeras hojas aparece, a modo de glosas, una aclaración al texto con letra similar más pequeña. Algunos califican este ejemplar como «uno de los grandes libros consoladores de la cristiandad».

Dado el delicado estado de conservación con una enfermedad incluida: «Grünspanfraß» (= cardenillo) - ¡tiene una vida de más de los mil doscientos años! - en la actualidad ha dejado de mostrarse y no se cede ya para exposiciones. Incomprensiblemente no existe una buena edición facsímil, la que se conserva data de los años 1969/70 y deja mucho que desear, cuando se tienen en cuenta las nuevas técnicas. Todo el salterio puede contemplarse en esta página de internet: https://archive.org/details/StuttgarterPsalter/page/n21/mode/2up.

Quienes escribieron y pintaron el libro de Stuttgart - el texto sigue el psalterium gallicacum en minúsculas; los títulos usan letras unciales y capitales - fueron monjes benedictinos de la abadía de Saint Germain des Prés, que entonces se encontraba fuera de los muros de París y que ahora está en el centro mismo de la ciudad. Aún se conserva su antigua iglesia románica, muy posterior a la confección del salterio. Seguro que gastaron mucho tiempo y esfuerzo para hacer tan bello ejemplar, aunque sin duda se fijaran en alguna copia anterior.

La investigación más reciente sostiene que los salterios carolingios dependen de un modelo de inicios del siglo V, cuando la literatura patrística alcanzaba un inusitado esplendor. Al hilo de los salmos se van inter- 
calando las ilustraciones, centrándose un buen número de ellas en la vida de David y de modo muy especial en la de Cristo, sobre todo la Pasión, alargándose hasta el Juicio Final. Nuestros monjes no han legado sus nombres a la posteridad. Para ellos importaba más la obra bien realizada que su identidad de autores. Las imágenes suponen un enternecedor diálogo ilustrado con Dios y Jesucristo. No sólo los salmos son oración, también podemos considerar como tal la contemplación de sus ilustraciones.

\section{Salmo 22 (21): «Dios mío, Dios mío, ¿por qué me has abandonado?»}

Ya hemos mencionado que una de las características más acusadas de los monjes pintores de este códice está en que interpretan sus salmos cristológicamente. Los rezamos no sólo en presencia y compañía de Cristo, que los rezó durante su vida terrena, también se los dirigimos a su persona de diferentes maneras y nos ponemos en su misma situación. «Como el Cristo total es cabeza y cuerpo - enseñaba San Agustín-, por eso en todos los salmos, al oír la voz de la Cabeza, oigamos la del Cuerpo». Así lo hemos adelantado ya y así podemos comprobarlo en los este ejemplo excepcional, que exponemos aquí.

Ya hemos señalado, también, que Jesús gritó en la Cruz, al menos el inicio del Salmo: «Dios mío, Dios mío, ¿por qué me has abandonado?» (Mc 15,34; Mt 27,46). El artista ha sabido unir aquí motivos del salmo con la escena de la crucifixión de Jesús, tal como es expuesta en los sinópticos, partiendo de Marcos. Un hombre bueno, que ha pasado la vida haciendo el bien, se encuentra en una situación límite, y acabará su vida muriendo crucificado. El autor del relato ha narrado la muerte de Jesús desde el salmo 22; algo que el artista sabe y quiere que, cuando nosotros lo recemos, hagamos los mismo en comunión con el Señor. Implícitamente lo hacen enmarcando las imágenes de la escena entre el texto del salmo en los versículos del 19 al 22.

$\mathrm{Y}$ así los motivos del salmo que entran en juego son dos preferentemente: las fieras que rodean al justo perseguido injustamente: «sálvame de las fauces del león; a este pobre, de los cuernos del búfalo» (versículo 22) y sortear la túnica: «se reparten mi ropa, / echan a suerte mi túnica» (versículo 19). Los dos motivos aparecen en la miniatura: Al lado derecho de la cruz están representados dramáticamente un unicornio, que se acerca peligrosamente con su cuerno al pecho de Jesús y un león rugiente. 
Son los representantes de las fuerzas del mal, que acabarán con el Justo por excelencia. Pero en la muerte se anuncia la resurrección, consistente en el definitivo ser en Dios.

En el plano bajo aparecen sentados dos hombres, que quieren repartirse la túnica, conforme dicen el salmo y los relatos evangélicos de la pasión (Mc 15,24; Mt 27,35; Lc 23,34; Jn 19,23s). El de la izquierda quiere partirla, pero el de la mano derecha hace gestos de que no lo haga, tirando de ella. Tienen que sortearla: «Era una túnica sin costura, tejida toda de una pieza de arriba abajo. Y se dijeron: "No la rasguemos, sino echémosla a suerte, a ver a quien le toca” (Jn 19,24). De esta manera se cumple lo que había anticipado mucho tiempo antes por el salmista.

A estos dos motivos el pintor ha añadido, que no está en el salmo y que hace relación a la crucifixión de Jesús, la confesión del centurión romano, representado junto con un segundo soldado: «El centurión, que estaba enfrente, al ver cómo había expirado dijo: "Verdaderamente este hombre era Hijo de Dios» (Mc 15,39; Mt 27,54; Lc 23,47). El artista da a esta escena gran importancia: está situada a la derecha de Jesús y en contrapunto con las fuerzas del mal. Con el dedo índice de su mano derecha el centurión está reconociendo la verdadera identidad de Jesús.

Quien muere en el madero de la cruz, no es bandido, que está pagando sus crímines, sino el Hijo de Dios, que unido al Padre de los cielos por los lazos íntimos de la una comunión sin límites y que ha derrochado su amor hasta el último suspiro por la humanidad encadenada al pecado. El Justo por excelencia, que no conoció el pecado y se mantuvo alejado de la injusticia, entrega incondicionalmente su vida por los injustos, que le llevaron al matadero. El Inocente muere para que los cumplables tengamos vida en abundancia.

\section{TRES SALTERIOS EXCEPCIONALES CON MINIATURAS DEL PN}

Me detengo en una tríada de salterios, que no solo contienen los 150 o 151 salmos, también ofrecen otros textos poéticos tanto del Primero como del Segundo Testamento, entre ellos la oración del Padre Nuestro 
con imágenes adecuadas al texto y maravillosa caligrafía. Entre los muchos y bellos que hay, elijo tres salterios del superlativo, que contienen no solo el texto sino también imágenes, mostrándonos cómo el PN se convierte en belleza de imágenes. Corresponden a tres épocas distintas del arte: al carologio, el románico y al principio del gótico. Usan el latín, la lengua que se hablaba en la liturgia, la teología y la espiritualidad en la Edad Media.

Podía haber elegido otros de gran belleza, pero al final me he decidido por estos tres, que ponen en imágenes la oración del PN con una significación especial. Además, tienen algunos elementos comunes, como situar detrás del PN el Credo y calificar al PN como «oratio dominica», resaltado en rojo.

\section{EI PN en el Salterio de Utrecht}

De la época del renacimiento cultural de Carlomagno (siglos VIII y IX) nos han quedado un buen número de códices con imágenes, casi todos ellos de carácter religioso y de extraordinaria belleza. Destacan las biblias, los salterios, los evangeliarios, los apocalipsis y los sacramentarios. Pero entre todos ellos sobresale el llamado «Salterio de Utrecht». Son muchos los que lo consideran como quizá la más famosa obra de la pintura carolingia en miniatura y uno de los ejemplos más temprano de un salterio ilustrado en esa clase de figuración en Occidente.

Sus representaciones han influido en pintores tan excepcionales como Durero, Leonardo da Vinci, Rembrandt, Van Gogh y Picasso, por señalar a algunos de los creadores más reconocidos internacionalmente. La Universiteit Utrecht ha digitalizado este códice único bajo el código: http://psalter.library.uu.nl. Existe edición facsímil en la Editorial Adeva de Graz (Austria).

Confeccionado en la abadía benedictina de Hautviller entre los años 820-840 por encargo del arzobispo de Reims Ebbo, hermano de leche del emperador Luis el Piadoso, contiene los 150 salmos, 16 cánticos, algunos fragmentos de los evangelios, entre ellos el padrenuestro, y el credo de los apóstoles.

En esta obra maestra sin par descuellan tres características: a) La originalidad de sus imágenes. No conocemos ninguna obra anterior, que haya podido servir de antecedente inmediato. Su autor expresó las ideas bíblicas 
existentes en el salterio con una fuerza creativa sin parangón. b) La simplicidad de sus trazos. El artista reduce su dibujo a lo esencial con gran fuerza imaginativa en la expresión del mensaje. Muestra con gran efectividad lo nuclear de lo que desea comunicar sin perderse en detalles innecesarios. c) La modernidad de sus ilustraciones. Sus figuras, llenas de movimiento y de expresividad, parecen comics realizados en el momento actual por un artista genial, profundamente religioso, que domina el dibujo como nadie.

Cuanto hemos dicho, vale para el modo cómo ha propuesto en imágenes el PN, que ofrecemos aquí. En medio de la naturaleza y en el corazón del mundo contemplamos a Jesús entre los doce apóstoles, seis a su derecha y seis a su izquierda, en movida actitud orante. Todos ellos sin excepción miran al cielo. Arriba del todo, hacia donde van dirigidas sus miradas, aparece la mano protectora y bienhechora del Padre, en señal de estar escuchando complacido la súplica de sus hijos. La sintonía entre el cielo y la tierra es perfecta.

Únicamente el Señor porta corona de santidad; solo Él, situado en el centro, se legitima como Maestro de oración, que ayuda a los suyos a mostrarse unidos y hermanados al amparo del Padre de los cielos. Abajo viene el texto latino del PN en letras mayúsculas, en tres columnas (la segunda y la tercera empiezan con «sicut»= según), que se leen perfectamente. Están encabezadas por el título en letras rojas: «Oratio dominica secundum Matheum» = «La oración del Señor según san Mateo». jExtraordinario!

Cuatro cosas destacan en esta creativa escena de sencilla belleza, la más difícil de conseguir.

1. Jesús ocupa el centro como autor, maestro y testigo de esta oración a la que volvemos una y otra vez los espectadores, de la misma manera que se han vuelto los orantes cristianos de todas las épocas. Escuchamos su voz, contemplamos su rostro, hacemos sus mismos gestos, cercanos como estamos de su persona con los ojos bien abiertos y los oídos atentos. Nos abrimos a la belleza de su oración, que desde que la pronunció se ha convertido también en la nuestra, a la que más recurrimos tanto en momentos alegres como tristes.

2. El Padre escucha a Jesús y nos escucha a nosotros. Su mano visible en lo alto del cielo nos está asegurando que no se desentiende de nosotros. Al contrario, está a nuestro lado complacido, conoce lo que decimos y hacemos y nos bendice por ello. El hace posible que 
nuestra vida se logre, ya que nuestras súplicas alcanzan su corazón que no vemos, pero que lo tiene muy grande.

3. El Espíritu invisible sopla sobre el grupo con fuerza, alentando todo lo que Jesús les está enseñando sobre la oración y moviéndoles a la acción. El que conozcamos ahora el PN, desafiando el espacio y el tiempo, se debe al hecho de que el Espíritu se mantiene siempre activo y no deja de acompañarnos mediante su inefable misterio, atendiendo nuestras necesidades.

4. Cuando el discípulo ora al Padre se sitúa en una actitud trascendente. En su cuerpo destacan sus brazos alzados, una forma bellísima de dirigirse al Altísimo. Aunque es nuestro Padre, nunca alcanzamos todo el amor que nos dispensa, siempre podemos darle más. El creyente tiene sed del Padre y nada más humano y religioso que levantar las manos en actitud de súplica.

5. El PN se reza en la inmensidad del universo, convertido en la casa que el Padre nos ha regalado y donde resuena una y otra vez nuestra plegaria. El orante no solo se pone en relación con Cristo, con el Padre, con el Espíritu, con los hermanos; lo hace también conectando con el cosmos. La creación entera está a su disposición para que su oración pueda ser escuchada, testimoniada y cumplimentada.

Impresiona contemplar cómo el autor de estas imágenes ha sabido crear un clima propicio, especialmente bello, para que tomemos muy en serio en nuestra vida la oración que nos enseñó el Señor y que conserva su atracción.

Si tuviéramos delante esta escena, cuando rezamos el PN, nunca se convirtiría en cansancio, monotonía y rutina. En él nos estamos jugando algo muy grande, estamos conectando con algo muy bello que pide de nosotros consideración y consciencia, disponibilidad y respuesta.

Consideración, sí, de la grandeza que nos está proponiendo en el PN; consciencia para tener presente lo que rezamos y dejemos a un lado las distracciones; disponibilidad para estar dispuestos a rezarlo con gozo, siempre que las circunstancias lo pidan; y respuesta, porque la oración del Señor cambia nuestros pensamientos y sentimientos, llegando al comportamiento responsable.

El Padre y Jesús quieren que nos abramos más como hijos y hermanos, que la filiación y la fraternidad, creación de la gracia, sea también el 
fruto de nuestra existencia, de modo que seamos conscientes siempre de ello y estemos prestos al testimonio.

Estamos plantados como árboles en este mundo, con raíces profundas y con las ramas hacia arriba, que constantemente están mostrando lo más noble del Padre, su disposición a atendernos y mostrarnos amor.

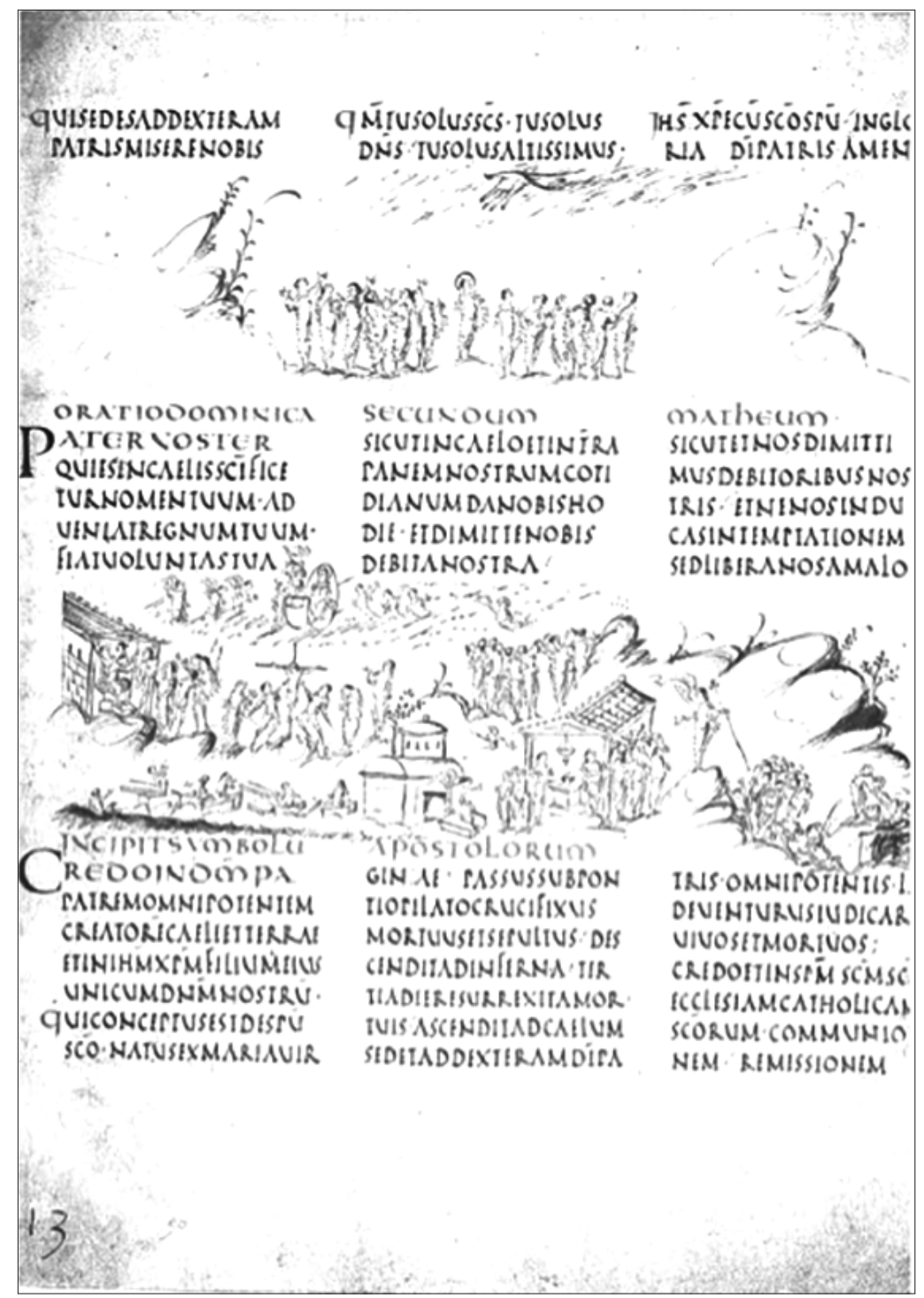




\section{El PN en el Salterio de San Albano}

Uno de los salterios más originales de la Edad Media proviene de la Abadía de San Albano, cercana a Londres y muy famosa en su tiempo. Se compuso en plena época románica, concretamente entre los años 11191146. Contiene un gran número de miniaturas de bella factura y excelente calidad. Fue encargado por su abad Geoffrey de Gorham para regalárselo a una mujer de fuerte compromiso religioso, llamada Christina de Markyate. Muy posiblemente actuó como su padre espiritual y quiso que tuviera un libro de oraciones e imágenes, que le ayudaran en su vida contemplativa en solitario. Y sin duda lo logró con creces.

Actualmente se encuentra en la biblioteca de la catedral de Hildesheim en la Baja Sajonia alemana. Tenemos la suerte de contar con una edición facsimile, publicada por una famosa editorial de Stuttgart. De igual modo que el anterior, podemos recurrir a Internet (abdn.ac.uk/stalbanspsalter), para hacernos con un estudio exhaustivo del manuscrito. Se nos ofrecen en un color espléndido todas sus miniaturas, incluso en sus detalles más sobresalientes, con la correspondiente valoración artística de cada una de ellas. El conjunto está realizado por un gran especialista inglés, que se ha especializado en este maravilloso códice. Merece la pena conocerlo.

Además de contar con un bellísimo ciclo de 40 miniaturas sobre la vida de Jesús y otro mucho más amplio aún de cada uno de los salmos, visualiza también algo más difícil de hacer: las oraciones y confesiones de la Iglesia, como es el caso del PN y del Credo, cuyas miniaturas ofrecemos aquí: arriba la referente al PN, abajo la del Credo. El texto latino de ambos destaca a mano derecha en cuidada caligrafía. En la imagen que ofrecemos el Credo sólo aparece el comienzo: «Credo in d(eu)m patrem omnipotentem creatorem celi \& terre», el resto viene en el mismo folio vuelto. El PN lo tenemos completo en la versión de la Vulgata. Corresponde a la página 396 derecha del códice.

Nos centramos ahora en el PN, titulado en pequeñas letras rojas «Oratio d(omi)nica»: «Oración del Señor». Las imágenes están incluidas en el redondel de una artística «P», la letra con que empieza: «Pater Noster». Arriba del todo se encuentra el busto de Dios, que de forma bien resaltable se asoma por encima de los muros de una bella Iglesia.

Contempla complacido y atento a un orante de pie, que dirige su plegaria con el rostro hacia arriba y con el brazo derecho levantado, apun- 


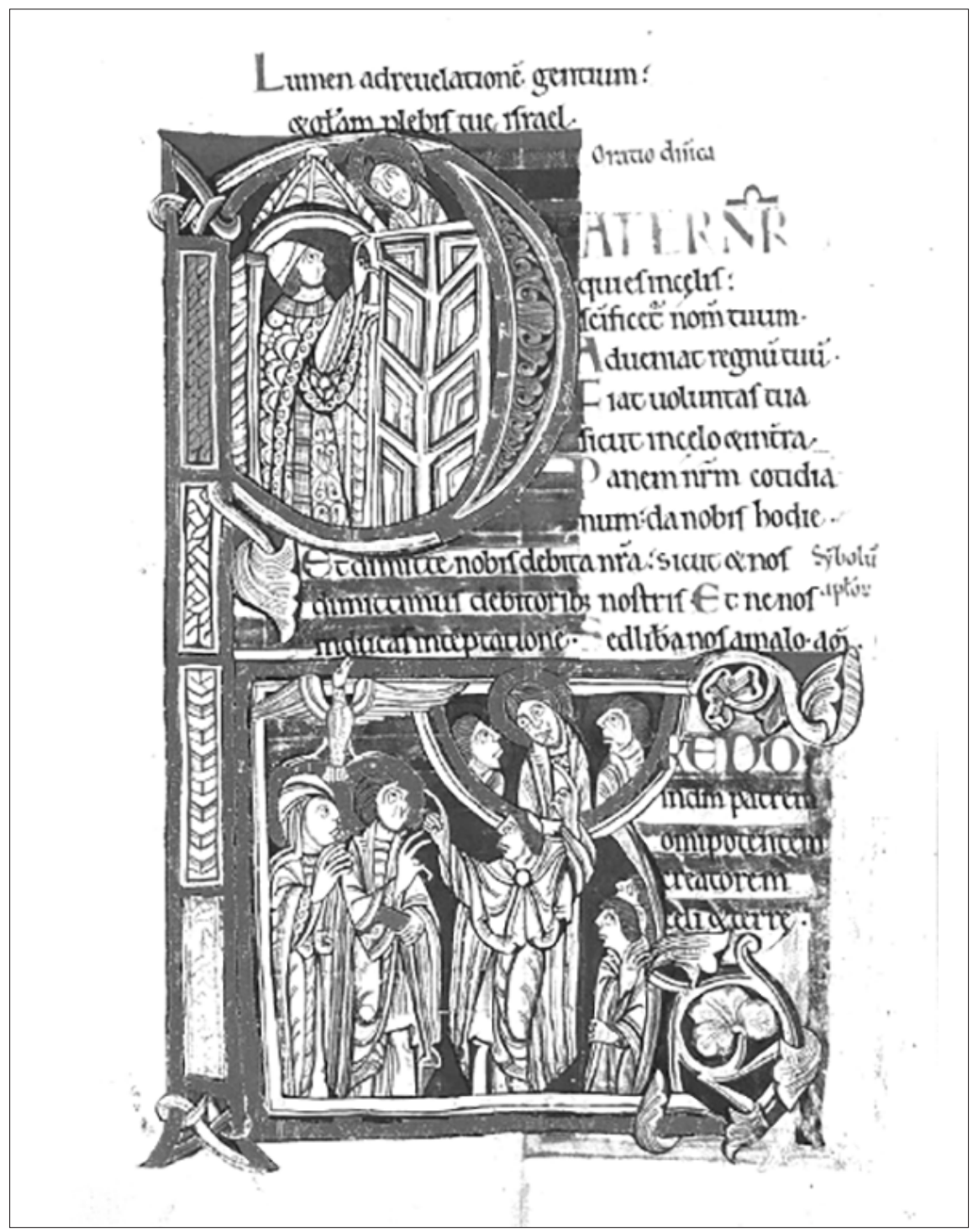

tando el dedo índice - los dedos tienen una especial significación en este códice - hacia donde se encuentra el Padre. Está plenamente convencido de que su oración va a ser debidamente atendida. Está vestido con bellas vestiduras sacerdotales bajo una cúpula. La corona del Padre aún sobresale por encima de ella. 
El conjunto desprende un gran encanto por su plasticidad, ingenuidad y sencillez. Muy posiblemente el monje artista quiso significar la fe confiada con que un mandatario eclesiástico, durante una solemne celebración litúrgica, reza la oración enseñada por el Señor. Con su actitud piadosa el presidente de la asamblea está sirviendo de ejemplo para todos aquellos que rezan el PN. No se encuentran en el ámbito del dibujo, pero se supone que acompañan al celebrante.

Los colores y las formas motivan la oración e interiorizan su mensaje. Al finalizar este comentario, nos interesa resaltar cómo los artistas del arte religioso por excelencia que es el románico, encontraron su inspiración también en la oración, que un día bendito Jesús de Nazaret, el Hijo de Dios y el Hermano de los hombres, nos enseñó a sus discípulos y en ellos a la humanidad entera.

\section{EI PN en el Münchner Goldener Psalter}

Al final del románico los artistas buscaban crear nuevas formas expresivas, para dar un mayor realismo a sus logros artísticos, puestos al servicio de la oración y espiritualidad. Entre los salterios producidos entre finales del siglo XII y principios del siglo XIII destaca la deslumbrante belleza del llamado Münchner Goldener Psalter. «Münchner», porque se conserva en la famosa Bayerischer Staatbibliothek (BSB Clm 835) de la capital bávara y «Goldener», porque está pintado con gran profusión de oro. Este bellísimo códice ha sido facsimilado en 2011 por Quaternio Verlag de Luzerna y su totalidad puede contemplarse en https://daten.digitale-sammlungen.de/ db/0001/bsb00012920/images/.

Muy posiblemente salió de talleres de la inglesa Oxford hacia el año 1200. Su encargo está en conexión con el priorato de San Guthlac en Hereford, un pequeño cenobio perteneciente a la abadía benedictina de Gloucester. Se piensa que fue un regalo de bodas hecho a Margaret de Briouze en su enlace matrimonial con Walter II. De Lacy, un consejero y protegido de Ricardo Corazón de León. Desconocemos quién encargó tan preciosa joya.

Contiene 27 bellísimas miniaturas del libro del Génesis, algunas sobre el rey David y sobre todo 19 escenas de la vida de Jesús. Entre otras riquezas. ofrece también una bellísima capitular «P» con un logrado dibujo de Jesús con sus discípulos. En el refinado redondel de la P se contempla 


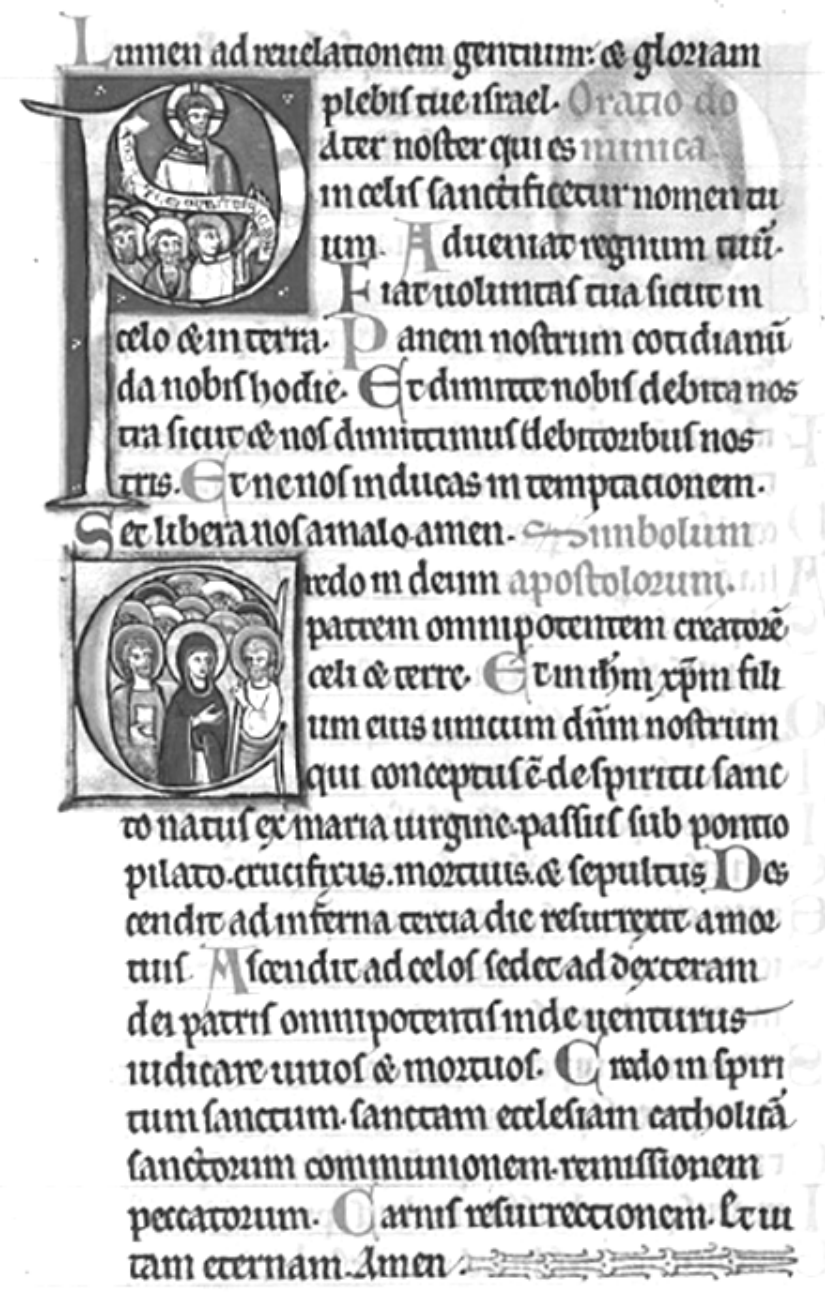

a Jesús en lo alto, dando el PN a los discípulos situados en la parte baja y separados por una cartela, que contiene la oración. Corresponde al folio 158 recto. Antes del inicio del Pater Noster en latín, situada a la derecha del dibujo se lee en finas letras trazadas en rojo la expresión «oratio dominica», la oración del Señor. 
En la misma página, inmediatamente después, se encuentra el Credo con otra hermosa capitular «C», dentro de ella descubrimos a María en el centro, rodeada de los apóstoles, los representantes más genuinos de la Iglesia universal. El PN y el Credo forman aquí una cerrada unidad, magistralmente conseguida. Podemos considerar el Credo como la explicación más autorizada del PN en la historia de la Iglesia. Tanto el PN como el Credo resumen toda la enseñanza cristiana como ningún otro texto: uno en forma de oración, otro de proclamación de la fe.

La lectura de un fragmento del Evangelio, la profesión del Credo y el rezo del PN constituyen tres momentos especialmente solemnes en la celebración eucarística, el acto central de la comunidad cristiana y el eje de su espiritualidad.

Con el rezo o canto del PN se cierra propiamente la plegaria eucarística, que constituye la presencialización de la Muerte y Resurrección de Cristo. Antes de recibir la comunión, el Resucitado nos invita a ponernos por la acción del Espíritu en manos del Padre y en estrecha relación con los hermanos del Hijo, nuestros propios hermanos.

La presencia de Cristo, hombre como nosotros, se hace transparente en la acción litúrgica, dirigida a los fieles participantes en ella. De ahí que los evangelios, el PN y hasta el Credo sean bellamente iluminados, para recordarnos quién es la Luz y de dónde recibimos la iluminación para orientar toda la vida hacia la plenitud.

\section{FINAL}

\section{Jesús, el más bello de los hombres}

San Agustín tiene un texto famoso, en el que habla de la hermosura del Verbo, comentando el Sal 44 (45), 3: «Eres el más bello de los hombres, / en tus labios se derrama la gracia, / el Señor te bendice eternamente»:

«Poco es no avergonzarte de ella, al contrario, debes incluso gloriarte en ella. ¿Por qué, entonces, no tuvo un aspecto atrayente? Porque Cristo crucificado fue un escándalo para los judíos y una locura para los paganos. ¿Y por qué, no obstante, hasta de la cruz le vino la hermosura? Porque la locura de Dios es más sabia que los hombres; y lo que es débil para Dios, 
es más fuerte que los hombres. Que a nosotros, que ya creemos, en cualquier situación que se nos presente, el Esposo sea bello. Hermoso por ser Dios, la Palabra con Dios; hermoso en el seno de la Virgen, donde no perdió su divinidad, y tomó la humanidad; hermoso como la Palabra recién nacida; porque aun siendo un infante sin palabras, al mamar, al ser llevado en brazos, los cielos hablaron, los ángeles cantaron alabanzas, una estrella guio a los Magos, fue adorado en el pesebre y manjar de los mansos. Es, pues, hermoso en el cielo, hermoso en la tierra, hermoso en el seno materno, hermoso en brazos de sus padres; hermoso en sus milagros, hermoso en los azotes; hermoso al invitar a la vida, hermoso no preocupándose de la muerte; hermoso entregando su vida, hermoso al recuperarla; hermoso en la cruz, hermoso en el sepulcro, hermoso en el cielo. Escuchad este cántico para entenderlo, y que la debilidad de la carne no aparte vuestros ojos del esplendor de su hermosura. La suprema y auténtica hermosura es la justicia; a nadie verás ser hermoso si lo encuentras malvado; si es totalmente justo, lo es también bello» ${ }^{3}$.

Jesús, el más bello de los hombres, nos legó la oración más bella jamás orada. Lo que reza Jesús en el PN no son ideas abstractas, sino pensamientos vitales y sentimientos vibrantes, que hacen latir el corazón ahora y siempre, rompiendo cualquier clase de desamor, cuando se ora de verdad. La auténtica belleza también ofrece estas mismas características. Tiene que ver con lo esencial de la vida de las personas, con su dignidad concreta, en el que cada uno se puede sentir reflejado, con el fuerte latir de lo íntimo. El PN y la belleza nos humanizan y nos sitúan en un ámbito trascendente de la condición humana, llegando al Padre de los cielos y a los hermanos de la tierra.

El PN nos propone algo admirablemente bello: Únicamente me comunico de verdad conmigo mismo en la medida que me comunico con el Padre y cuando lo hago también con los hermanos. Esta bendita oración nos rescata de la soledad del «yo» y nos pone en la órbita del «Tú» y del «nosotros», de la filiación compartida y la fraternidad, coordenadas vitales, en las que la persona se siente agraciada. ¿Puede haber algo más bello que establecer estos vínculos tan firmes, estas comuniones tan entrañables, para buscar el cariño, adherirse a la reciprocidad y salir de la fragilidad?

${ }^{3}$ Exposición del salmo [o Exp. Sal.] 44,3. Obras completas de san Agustín XX, BAC 246, Madrid 2018, 426. 
¡El PN cuida nuestro desvalimiento y lo cura! Los valores humanos del PN condensan el Evangelio y esto lo han conocido todos los orantes, acogiéndolo con gratitud.

En el PN necesitamos al Padre, pero también el Padre nos necesita a nosotros, para formar con los que más quiere una familia unida. En esta oración necesitamos a los hermanos, pero también ellos nos necesitan para formar la gran fraternidad humana en la que no falte nadie. ¿Puede haber algo más bello? La belleza de las súplicas del PN está en que no busca ceder, dejando las cosas como están. Bien rezadas, están llamadas a producir en nosotros cambios profundos, que llevan a la conversión del corazón.

El orante del PN se convierte en un profeta que busca la paz, que brota en la vida real mediante la experiencia del Padre y la entrega a los hermanos. En la belleza de esa paz nace un hombre nuevo, testigo de los dones trascendentes, que confiesa la fe, se orienta hacia la esperanza y vive el amor con intensidad. Qué bonito, qué consolador si rezamos el PN con estas actitudes teologales y escuchamos lo que el Espíritu quiere transmitir como venido de Cristo, el Hijo del Padre.

En el PN el Espíritu está orando en nosotros. San Pablo lo ha expresado de una manera inigualable: «Dios envió a nuestros corazones el Espíritu de su Hijo, que clama “¡Abba, Padre!»(Gal 4,6). «Habéis recibido un Espíritu de adopción, en el que clamamos “;Abba, Padre!»(Rom 8,15). En el PN nos dirigimos al Padre, pero también el Padre se dirige a nosotros, en realidad él reza en nosotros bajo la acción del Espíritu, que se derrama en nuestros corazones. «Ese mismo Espíritu da testimonio a nuestro espíritu de que somos hijos de Dios» (Rom 8,16). Y este testimonio del Espíritu del Padre y del Hijo y el testimonio de nuestro propio espíritu hacen nuestro rezo del PN aún más atrayente y bello.

\section{La respuesta del Padre a nuestra oración}

La belleza del PN adquiere nuevo resplandor, cuando lo escuchamos «desde el otro lado»: desde la respuesta del Padre entrañable, que ha aceptado nuestra oración y le da cumplida contestación. Así ha ideado esa respuesta el jesuita José María RodríGuez Olaizola:

Hijo mío, que estás en la tierra, haz que tu vida sea 


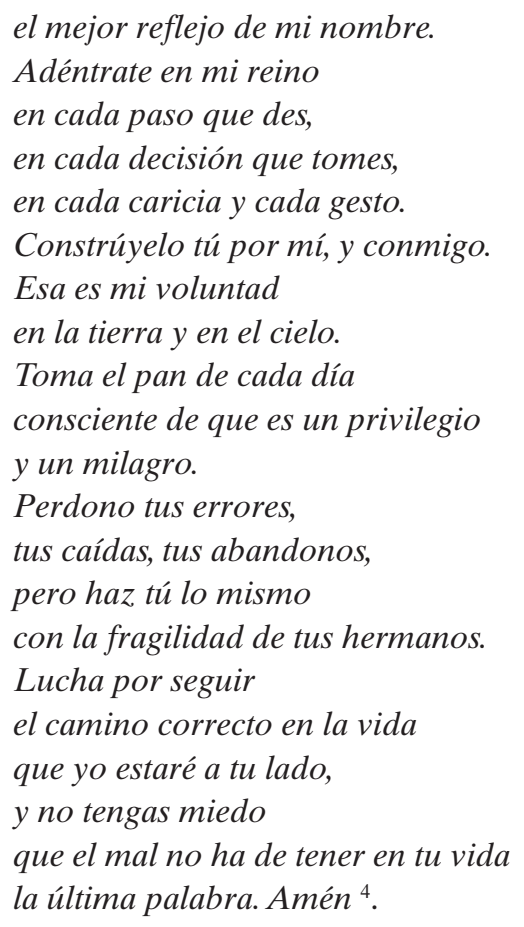

En el fondo todo se concentra en aceptar la soberanía del Padre, que tiene en el Hijo Jesús a su profeta anunciador; soberanía que se muestra sobre todo en su bondad, protectora de la humanidad entera. Estamos llamados a responder a los valores que se derivan de esa bendita grandeza, oculta en sus inicios, pero que logra imponerse, cuando el PN se va haciendo más consciente y operante en el comportamiento personal del orante en la relación con sus semejantes. El Padre busca el bien de todos sus hijos, que acaba redundando en beneficio propio. Su amor late dentro del orante y da respuesta a sus buenos propósitos, manifestados en las acciones posteriores. ¡Una última belleza!

\section{Desenlace}

Como hemos dejado claro en nuestra exposición, el PN nos proporciona una buena noticia en estado puro sobre el Dios Trino, que es Padre,

\footnotetext{
${ }^{4}$ Jesuitas Nr. 132 (primavera 2017) 9.
} 
Abba sin ocultamientos de ninguna clase. Está lleno de bondad sin posibilidad de maldad alguna. Se encuentra junto a cada uno de nosotros, acompañando sin cesar nuestra trayectoria vital. Perdona nuestros pecados, nos sostiene en la tentación y nos libra del mal. Vuelto incondicionalmente hacia todas las personas, se muestra en el Hijo bajo la acción del Espíritu, como el Amor Sumo, la Verdad Suprema, la Belleza Absoluta. Así lo podemos proclamar, cuando como orantes tenemos experiencia de Quién es Él y cómo se comporta.

Al mismo tiempo el PN nos descubre la verdadera realidad del ser humano, que hace de cada uno en el ámbito de lo creado un ser único. Como persona ocupa el centro de cuanto somos, hacemos y rezamos. Esa verdadera realidad, que sostiene su existencia, tiene una dignidad inigualable, una grandeza sin par entre los demás seres del universo. Está dotado de libertad, de grandes cualidades, que le permiten reaccionar en el debido tiempo y también aceptar la responsabilidad, para cumplir la voluntad divina más allá de los conflictos que nos depara el discurrir diario. En el PN no hay ideología, sino contemplación de lo existente tal cual es, tal como se realiza d acuerdo con los designios divinos de salvación.

Padre bueno, presérvanos de la arrogancia y de las autojustificaciones injustas, que nos apartan de los humildes y sencillos. No nos hagas insensibles a los valores humanos, alejános del comportamiento agresivo y de aferrarnos solo a lo nuestro sin preocuparnos de los demás. Danos un corazón sensible de hijos y hermanos, bien dispuesto en sus decisiones, libre de miedos infundados, compasivo y misericordioso, abierto al diálogo y dispuesto a servir, procurando compartir la vida con los más necesitados de pan material y de valores espirituales. Tú eres quien activas en nosotros «el querer y el obrar para realizar tu designio de amor» (Fil 2,13).

Jesús nos legó todas estas actitudes en el PN y así queremos seguir conservándolas, para ser semejantes a él y permanecer fieles a su seguimiento. No podemos enterrar la belleza, por eso estamos llamados a seguir rezándolo con plena consciencia de lo que dirigimos a lo alto en compañía de los hermanos. Sería imperdonable convertirlo en rutina o dejar de rezarlo debidamente. El Padre nos llama continuamente en esta bendita oración. Nuestra grandeza consiste en que cada día recemos sus peticiones con autenticidad. El PN entra en cada orante con corazón sincero como amor y verdad, arte y belleza. Si algo tiene que perdurar en la existencia diaria del creyente es la oración trinitaria de Jesús y los cristianos. 